\title{
The Influence of Tilia tomentosa MOENCH on Plant Species Diversity and Composition in Mesophilic Forests of Western Romania-A Potential Tree Species for Warming Forests in Central Europe?
}

\author{
Steffi Heinrichs ${ }^{1,2}\left(\mathbb{D}\right.$, Veronika Öder ${ }^{3}$, Adrian Indreica ${ }^{4}$, Erwin Bergmeier $^{3}\left(\mathbb{D}\right.$, Christoph Leuschner $^{5}$ \\ and Helge Walentowski ${ }^{1, *(\mathbb{D})}$
}

1 Faculty of Resource Management, HAWK University of Applied Sciences and Arts, Büsgenweg 1a, 37077 Göttingen, Germany; sheinri@gwdg.de

2 Department Silviculture and Forest Ecology of the Temperate Zones, University of Göttingen, Büsgenweg 1, 37077 Göttingen, Germany

3 Vegetation \& Plant Diversity Analysis, Albrecht von Haller Institute, University of Göttingen, Untere Karspüle 1a, 37073 Göttingen, Germany; v.oeder@posteo.de (V.Ö.);

Erwin.Bergmeier@bio.uni-goettingen.de (E.B.)

4 Department of Silviculture, Transilvania University of Braşov, Şirul Beethoven 1, 500123 Braşov, Romania; adrianindreica@unitbv.ro

5 Plant Ecology, Albrecht von Haller Institute for Plant Sciences, University of Goettingen, Untere Karspüle 2, 37073 Göttingen, Germany; cleusch@gwdg.de

check for

updates

Citation: Heinrichs, S.; Öder, V.; Indreica, A.; Bergmeier, E.; Leuschner, C.; Walentowski, H. The Influence of Tilia tomentosa MOENCH on Plant Species Diversity and Composition in Mesophilic Forests of Western Romania-A Potential Tree Species for Warming Forests in Central

Europe? Sustainability 2021, 13, 7996 https://doi.org/10.3390/su13147996

Academic Editor: Ashraf Dewan

Received: 30 June 2021

Accepted: 15 July 2021

Published: 17 July 2021

Publisher's Note: MDPI stays neutral with regard to jurisdictional claims in published maps and institutional affiliations.

Copyright: (c) 2021 by the authors. Licensee MDPI, Basel, Switzerland. This article is an open access article distributed under the terms and conditions of the Creative Commons Attribution (CC BY) license (https:// creativecommons.org/licenses/by/ $4.0 /)$.
* Correspondence: helge.walentowski@hawk.de; Tel.: +49-551-5032-177
Abstract: Climate change challenges important native timber species in Central Europe. The introduction of non-native tree species originating from warmer climates is one option to make Central European forests compatible to global warming. This, however, requires an assessment of the species' growth requirements, and of its impact on biodiversity in its native ranges. Silver lime (Tilia tomentosa), a moderately drought-tolerant, thermophilous tree species of South-eastern Europe is considered suitable for the future. Along three elevational transects in western Romania, we assessed the impact of changing climate and local site conditions on the abundance of this tree species and contrasted plant species diversity and composition of lime-dominated forests with mesophytic oak and beech forests. Local site conditions and disturbance histories shaped the distribution pattern of silver lime. When dominant, it reduced plant species diversity within stands due to its dense canopy. For shade-tolerant, mesophytic species, though, lime forests provided an additional habitat and extended their range into warmer environments. Thus, silver lime may have the potential as an admixed tree species forming a transitory meso-thermophilous habitat in the future. At the same time, silver lime may be limited under increasing drought frequency.

Keywords: assisted migration; climate change; non-native tree species; habitat function; lime forests; oak forests; complementarity; gamma diversity; European beech forests; elevational gradient

\section{Introduction}

Climate change with increasing temperatures and seasonal changes in the precipitation regime will affect the characteristic tree species composition of Central Europe by inducing range shifts of tree species and by increasing tree mortality [1-3]. First and foremost, the naturally dominant European beech (Fagus sylvatica L.) will be affected [4-6]. Increased tree species mortality, however, may also contribute to diversifying the tree species portfolio $[7,8]$ with positive effects for forest stability and multifunctionality $[9,10]$. In this respect, the introduction of non-native tree species originating from warmer climates and measures such as assisted migration have been discussed to maintain forest functionality [11,12]. Thereby, investigating tree species from regions where the climate 
already resembles projections for future climates in Central Europe can give important insights on the suitability of new tree species adapted to future trajectories $[13,14]$.

Silver lime (Tilia tomentosa MOENCH) is native to South-eastern Europe and characterized as thermophilous. It is regarded as a possible future forest tree species in Central Europe originating from analogous climate regions $[13,15]$. Its native range mainly covers the south-eastern edge of Central Europe, much of the Balkan peninsula and north-western Turkey. As the northern distribution limit, Hungary and north to north-western Romania are mentioned [16-18]. Currently, it is a well-known horticultural tree species in urban environments across Europe [16,19]. The species is characterized as fairly drought-tolerant and drought-resilient. It can tolerate precipitation values as low as $500 \mathrm{~mm}$, when equally distributed across the year, and mean annual temperatures between 10.0 and $11.5^{\circ} \mathrm{C}$ [16]. In mixed oak-hornbeam-lime stands affected by severe droughts, silver lime was able to recover its crown faster than other admixed tree species [20]. It regenerates by seeds or by resprouting even under a closed canopy, it is characterized by a fast growth rate in the first five to six decades and is resistant against pathogens [16]. First establishment trials in Central Europe show a low mortality of seedlings and successful establishment in the first years after planting [15]. Its preference for soils with a relatively good water holding capacity in the native range [18], however, raise questions concerning drought limitations under more frequent and intense droughts.

The introduction of non-native tree species also aims for a successful ecological integration in the new range. The fact that T. tomentosa was part of the Central European vegetation before the last ice age $[21,22]$ and its relatedness to the Central European Tilia species [18] may represent good preconditions for the adaptability of Central European biodiversity to silver lime. Nevertheless, to adequately assess the suitability and functioning of new tree species in the future, solid analyses in the species' native range are required to understand potential impacts on native biodiversity. In South-eastern Europe, T. tomentosa shows a broad ecological range. It is associated with mesophytic oak forests of Quercus petraea s.l. as well as with thermophilious oak forests of $Q$. cerris and $Q$. frainetto and is often admixed in stands formed by various Acer species, Carpinus betulus, C. orientalis, Castanea sativa, Fraxinus ornus and Ostrya carpinifolia [23]. In marginal sites of European beech (Fagus sylvatica), it is also part of beech forest communities [24-26]. Under specific conditions, it can form monodominant forests e.g., on northern slopes with neutral to slightly acidic soils and relatively high soil moisture. Such lime forests, listed as the European Union Habitat type $91 \mathrm{Z0}$ (Moesian silver lime woods), often have a rich spring flora [27]. T. tomentosa can also reach dominance after intensive or deficient forest management activities or following natural disturbances due to its pronounced resprouting ability $[20,28,29]$. Pure stands have also been promoted for honey production in former times across the Balkans and Northern Tukey [30]. According to Jacquemart et al. [31], T. tomentosa has a higher nectar sugar concentration than T. platyphyllos and T. codata and offers more flowers, more nectar, and more pollen than other Tilia species. It is a late flowering Tilia species and could therefore complement the native earlier flowering species of Central Europe. Like European beech, pure stands of Tilia species are characterized by a low light availability [32], with the bark of the stems being susceptible when suddenly exposed to direct sunlight. This may explain the strong association of silver lime with more shady high forests compared to coppice forests despite its good resprouting ability [33]. It is, however, not well known to what extent $T$. tomentosa may provide alternative habitats for mesophytic, shade-demanding species that require a stable forest microclimate under changing climatic conditions [5].

To understand patterns of establishment of $T$. tomentosa in its native range, its effects on plant species diversity and composition in thermo- to mesophilous forests and its potential functionality for understorey diversity in a changing climate, we conducted vegetation surveys along three elevational transects in western Romania covering a natural, climate-induced vegetation gradient from thermophilous oak forests in the lowlands to mesic montane beech forests. Due to its favourable influence on the internal forest 
environment and on stand productivity, silver lime was promoted in Romanian silviculture as an admixed species mainly in mesophytic oak forests [28,34].

Our study had two main goals: (1) We aimed to identify dependencies of T. tomentosa abundance on climatic variables that change with elevation. (2) We compared plant species diversity and composition among forests dominated by European beech, mesophytic oak (Quercus petraea s.l.) and silver lime under similar soil conditions and landscape configurations. With this, we aimed to analyse the potential position of silver lime under scenarios assuming a transition from dominant beech towards oak forests in Central Europe in the future [35]. We used the elevational transects as a space-for-time substitution approach mirroring a potential shift of forest communities by a predicted temperature increase. We generally expected a negative effect of $T$. tomentosa on plant species richness due to limited light availability but expected an intermediate position in terms of species composition between beech and oak forests due to its wide ecological range providing habitat for meso-thermophilous species. The analyses attempt to provide insight if and how T. tomentosa may affect understorey diversity if integrated in Central European forest landscapes under climate change.

\section{Materials and Methods}

\subsection{Study Areas}

Data were collected in western Romania along three elevational transects selected to observe the natural transition from thermophilous oak forests in the lowlands to mesic montane beech forests. The transects, named after the nearest locality, were Milova, Maciova and Eşelniţa (Table 1, [36]). All three study areas are characterized by siliceous bedrock covered with loess and relatively nutrient-rich soils with a good water storage capacity [36]. The surveyed elevational range was 200 to $700 \mathrm{~m}$ in Milova and Maciova and 200 to $900 \mathrm{~m}$ in Eşelniţa. The climate can be characterized as warm-temperate and humid with warm summers (Cfb climate) according to Kottek et al. [37]. Each transect covered a temperature gradient $\geq 3-4 \mathrm{~K}$ from lowest to highest elevation (Table 1).

The transects were characterized by mature forests between 70 (Maciova) and 95 (Milova) years of age managed as high forests by group selection cutting according to management plans of the local forest authorities. Areas dominated by silver lime showed traces of recent management, though the canopy cover was dense. Before 1960, stands were often coppiced or were affected by irregular wood cutting particularly close to settlements. In Eşelniţa, stands were also used as wood pastures in the past. Currently, forest stands are regularly thinned removing up to $15 \%$ of the growing stock decreasing with stand ageing [38]. The last thinning took place ca. 15 (Maciova) to 30 (Eşelniţa) years before data sampling. Occasional salvage and sanitary loggings with low intensity $(<5 \%$ of the growing stock) took place but no major harvesting operations occurred in the past 20 years [for more details see 36]. Tree density was generally high with average stem densities of $737 \mathrm{n} \mathrm{ha}^{-1}$ in Milova, $500 \mathrm{n} \mathrm{ha}^{-1}$ in Maciova and $595 \mathrm{n} \mathrm{ha}^{-1}$ in Eşelniţa and a comparable mean basal area of $34 \mathrm{~m}^{2} \mathrm{ha}^{-1}$ in all three study areas. All investigated stands originated from natural regeneration. Disturbance history slightly differed among study areas. Forest fires affected stands in Maciova and Eşelniţa in the 1940s, which likely promoted the establishment of silver lime, birch and aspen. After the Second World War, most forests of Maciova were clear-cut. The forests in Milova were intensively used, especially in the period before the Second World War, promoting the expansion of silver lime (A. Petriţan, personal communication). Repeated coppicing here further promoted the expansion of Tilia tomentosa in former times due to its high resprouting ability [20].

The studied transects covered a vegetation sequence from relatively dry thermophilous oak forests (Potentillo micranthae-Quercetum dalechampii) to mesophilous oak-hornbeam forests (Lathyro hallersteinii-Carpinetum) to mesophilous beech-dominated forests (mainly Festuco drymejae-Fagetum) [39]. T. tomentosa occurred mainly in mid-elevations (Table 1). 
Table 1. Characteristics of the three study areas in western Romania. For mean values, the standard deviation ( \pm SD) is given and the minimum and maximum values in parentheses. Climate variables were derived from CHELSA data [40]. Given are minimum and maximum values extracted for the investigated elevational range. The table also shows the number of plots with occurrence of Tilia tomentosa in the tree layer ( $>9 \mathrm{~m}$ height; with total number of survey plots in parentheses) and the share of different tree species (of total tree species cover) within these plots and the mean species richness in plots with T. tomentosa.

\begin{tabular}{|c|c|c|c|}
\hline & Milova & Maciova & Eşelniţa \\
\hline $\begin{array}{l}\text { Location } \\
\text { Area } \\
\text { Region }\end{array}$ & $\begin{array}{c}46^{\circ} 07.627^{\prime} \mathrm{N}, 21^{\circ} 47.963^{\prime} \mathrm{E} \\
268 \text { ha } \\
\text { Zarand Mountains }\end{array}$ & $\begin{array}{c}45^{\circ} 31.488^{\prime} \mathrm{N}, 22^{\circ} 12.824^{\prime} \mathrm{E} \\
229 \mathrm{ha} \\
\text { Poiana-Ruscă }\end{array}$ & $\begin{array}{c}44^{\circ} 44.025^{\prime} \mathrm{N}, 22^{\circ} 20.710^{\prime} \mathrm{E} \\
254 \text { ha }\end{array}$ \\
\hline Region & Zarand Mountains & Poiana-Ruscă Mountains & Almăj Mountains \\
\hline Bedrock & $\begin{array}{c}\text { Slate and granite covered with } \\
\text { loess }\end{array}$ & $\begin{array}{c}\text { Sandstone (with some } \\
\text { pyroclastic areas) covered } \\
\text { with loess }\end{array}$ & $\begin{array}{c}\text { Gneiss and granite covered } \\
\text { with loess }\end{array}$ \\
\hline Soil & & Base-rich Luvisols and Cambisols & \\
\hline Mean stand age (years) & 95 & 70 & 90 \\
\hline Annual temperature ( $t_{\text {avg }}$ in & 7.9-10.9 & $8.2-11.0$ & $7.8-11.8$ \\
\hline $\begin{array}{c}\text { Annual precipitation (Prec in } \\
\mathrm{mm} \text { ) }\end{array}$ & $679-892$ & $806-951$ & $583-844$ \\
\hline $\begin{array}{l}\text { Investigated elevational range } \\
\text { [m a.s.l.] }\end{array}$ & $253-762$ & $290-717$ & $170-907$ \\
\hline $\begin{array}{l}\text { Elevational range of plots } \\
\text { with T. tomentosa [m a.s.l] }\end{array}$ & $343-729$ & $321-650$ & 190-795 \\
\hline $\begin{array}{c}\text { Number of plots with } T \text {. } \\
\text { tomentosa }\end{array}$ & $\begin{array}{l}44(89) \\
49.4 \%\end{array}$ & $\begin{array}{l}42(96) \\
43.8 \%\end{array}$ & $\begin{array}{c}94(159) \\
59.1 \%\end{array}$ \\
\hline $\begin{array}{l}\text { Ellenberg Quotient (EQ) of } \\
\text { plots with T. tomentosa }\end{array}$ & $\begin{array}{c}25.8 \pm 2.5 \mathrm{a} \\
(20.6-30.2)\end{array}$ & $\begin{array}{l}23.0 \pm 1.2 \mathrm{~b} \\
(21.2-25.9)\end{array}$ & $\begin{array}{l}31.6 \pm 3.6 \mathrm{c} \\
(23.6-39.3)\end{array}$ \\
\hline \multicolumn{4}{|c|}{ Tree species shares in plots with T. tomentosa [\%] } \\
\hline T. tomentosa & $\begin{array}{l}49.6 \pm 33.4 \mathrm{a} \\
(0.5-100)\end{array}$ & $\begin{array}{c}26.5 \pm 27.4 \mathrm{~b} \\
(0.1-100)\end{array}$ & $\begin{array}{l}26.1 \pm 20.8 \mathrm{~b} \\
\quad(0.4-97.2)\end{array}$ \\
\hline F. sylvatica & $\begin{array}{l}11.3 \pm 21.4 \mathrm{a} \\
(0-85.0)\end{array}$ & $\begin{array}{l}30.1 \pm 35.6 \mathrm{~b} \\
(0-97.2)\end{array}$ & $\begin{array}{l}27.1 \pm 33.5 b \\
(0-96.2)\end{array}$ \\
\hline $\begin{array}{l}\text { Mesophilous oak }(Q . \\
\text { petraea/robur) }\end{array}$ & $\begin{array}{c}27.3 \pm 28.4 \mathrm{ab} \\
(0-94.1)\end{array}$ & $\begin{array}{c}19.3 \pm 27.8 \mathrm{a} \\
(0-97.2)\end{array}$ & $\begin{array}{l}33.3 \pm 28.8 b \\
(0-97.2)\end{array}$ \\
\hline $\begin{array}{l}\text { Thermophilous oak ( } Q . \\
\text { frainetto/cerris) }\end{array}$ & $\begin{array}{c}1.1 \pm 5.4 \mathrm{a} \\
(0-35.7)\end{array}$ & $\begin{array}{l}5.4 \pm 15.3 \mathrm{a} \\
(0-57.1)\end{array}$ & $\begin{array}{l}1.2 \pm 9.1 \mathrm{a} \\
(0-84.8)\end{array}$ \\
\hline Carpinus betulus & $\begin{array}{c}7.1 \pm 12.2 \mathrm{ab} \\
(0-50.0)\end{array}$ & $\begin{array}{l}13.1 \pm 17.1 \mathrm{a} \\
\quad(0-70.2)\end{array}$ & $\begin{array}{l}4.6 \pm 12.3 b \\
(0-80.0)\end{array}$ \\
\hline \multicolumn{4}{|c|}{ Species richness of plots with T. tomentosa } \\
\hline Tree layer & $\begin{array}{l}3.3 \pm 1.3 \\
(1-6)\end{array}$ & $\begin{array}{c}3.3 \pm 1.3 \\
(1-7)\end{array}$ & $\begin{array}{l}3.7 \pm 1.1 \\
(2-7)\end{array}$ \\
\hline Shrub layer & $\begin{array}{c}1.5 \pm 1.3 \mathrm{a} \\
(0-6)\end{array}$ & $\begin{array}{c}2.1 \pm 2.0 \mathrm{ab} \\
(0-7)\end{array}$ & $\begin{array}{l}2.2 \pm 1.6 \mathrm{~b} \\
(0-8)\end{array}$ \\
\hline Herb layer & $\begin{array}{l}15.5 \pm 7.2 \mathrm{a} \\
(3-37)\end{array}$ & $\begin{array}{l}16.4 \pm 6.2 \mathrm{a} \\
\quad(5-31)\end{array}$ & $\begin{array}{l}22.7 \pm 8.0 b \\
(6-46)\end{array}$ \\
\hline
\end{tabular}

Different letters show significant differences among study areas.

\subsection{Data Collection}

Vegetation data were collected in $200 \mathrm{~m}^{2}$ plots $(10 \times 20 \mathrm{~m})$ in May and July/August 2018/19 (Milova, Maciova) and in May and July/August 2019 (Eşelniţa) along the ridges of the transects. The plots were arranged systematically (at intersections of a $200 \times 200 \mathrm{~m}$ grid) in zones of $250 \mathrm{~m}$ width across the ridges using QGIS (Version 2.18-Palmas) and a geo-referenced DEM model (approx. $30 \mathrm{~m} \times 30 \mathrm{~m}$ ) (EEA EU-DEM). The grid-based sampling was completed by some additional surveys on neighbouring ridges based on expert opinion. In total 344 vegetation surveys (relevés) were conducted. In each relevé, all vascular plant species were recorded separately for the tree layer (woody plants $>9 \mathrm{~m}$ ), the shrub layer (woody plants $<9 \mathrm{~m}$ and $>1 \mathrm{~m}$ ) and the herb layer (woody plants $<1 \mathrm{~m}$ and non-woody plants). Total cover values per layer were recorded in percent, single species cover values according to a modified 9-figured Braun-Blanquet-scale. For data analysis, scale values were transformed into percent values as follows: $\mathrm{r}=0.1 ;+=0.5 ; 1=2.5 ; 2 \mathrm{~m}=5$; $2 \mathrm{a}=10 ; 2 \mathrm{~b}=20 ; 3=37.5 ; 4=62.5 ; 5=87.5$ [41]. Grid-based plots were excluded from sampling if they were structurally inhomogeneous or characterized by skidding tracks, roads, forest clearings or thickets. The nomenclature of species follows Sârbu et al. [42]. 
For each relevé, geographic and topographic information were recorded including GPS coordinates, elevation, slope inclination and slope aspect. Slope aspect was recorded in degrees $\left({ }^{\circ}\right)$ but transformed into an index from 1 (north-facing slopes) to 9 (southfacing slopes between $180^{\circ}$ and $203^{\circ}$ ) roughly scaling the potential amount of temperature and light a plot receives [43]. As a surrogate for local site factors, we calculated mean Ellenberg indicator values per plot (unweighted averages) for moisture, soil reaction and nitrogen [42].

We also calculated mean annual temperature values $\left(\mathrm{T}_{\text {avg }}\right.$ in $\left.{ }^{\circ} \mathrm{C}\right)$ and annual precipitation sums (PREC in $\mathrm{mm}$ ) per plot to relate the abundance of T. tomentosa to climate variables within its range of occurrence. As raster data for monthly temperature and precipitation, we used the high resolution CHELSA data (resolution of $30 \mathrm{arcsec}$ ) provided for the period 1979 to 2013 [40].

\subsection{Data Assessment}

We compiled two datasets:

(1) Silver Lime dataset: This dataset contained plots with $T$. tomentosa in the tree layer, i.e., 180 out of 344 relevés, or $43.8-59.1 \%$ of all survey plots in the three study areas (Table 1).

(2) Beech/Oak/Lime dataset: To compare species richness and composition among forest stands dominated either by T. tomentosa, Q. petraea or F. sylvatica, we grouped the relevés according to the target tree species' share on total tree layer cover (cover sum of all species $>9 \mathrm{~m}$ in height). Survey plots were grouped as representing lime-, oakor beech-dominated forests (henceforth the forest types are named lime, oak and beech forests), when the target tree species had a share $>50 \%$ of total tree layer cover irrespective of the identity of admixed tree species. To reduce the potential influence of confounding effects on differences among forest types, we only concentrated on the elevational range with T. tomentosa dominance in the tree layer per study area (200-750 $\mathrm{m}$ a.s.l. for Eşelniţa and between 300 and $700 \mathrm{~m}$ for Milova and Maciova), and a mean soil reaction value per plot of $\geq 5$, as $T$. tomentosa was not found in the tree layer at lower soil reaction values. In total, we included 226 out of the 344 relevés into this dataset. All plots not being dominated by silver lime, sessile oak or beech were not considered.

\subsubsection{Assessment of the Silver Lime-Dataset}

To identify potential drivers of the abundance of T. tomentosa in the canopy and understorey, we built linear models with the cover of $T$. tomentosa in the tree, shrub and herb layer as response variable and abiotic variables as potential influencing factors. For each response variable, we also tested the impact of the study area (Milova, Maciova and Eşelniţa) and its interaction with each abiotic variable. To find the most influencing factor for each response variable, we built global models with multiple predictors. For the cover of T. tomentosa in the tree layer (Cov_Tilia_TL), we considered mean annual temperature $\left(\mathrm{T}_{\mathrm{avg}}\right)$ and annual precipitation sum (Prec), the indicator values for moisture (M), soil reaction $(\mathrm{R})$ and nitrogen $(\mathrm{N})$ as well as slope and aspect-index (Global model 1: Cov_Tilia_TL transect $*\left(\mathrm{~T}_{\mathrm{avg}}+\right.$ Prec $+\mathrm{M}+\mathrm{R}+\mathrm{N}+$ slope + aspect $\left.)\right)$. For T. tomentosa in the understorey, we additionally considered the total cover of the tree layer (sum of cover values of species in the tree layer) as a measure for light availability in the understorey [44], the species richness of the tree layer indicating heterogeneity in light conditions [45], the share of $T$. tomentosa of total tree layer cover as a measure for the availability of seed sources, and the share of F. sylvatica and Q. petraea of total tree layer cover to assess a potential effect of the main accompanying tree species on the regeneration of T. tomentosa (Cov_Tilia_reg). We built two separate global models for the regeneration of $T$. tomentosa in the shrub $(>1 \mathrm{~m}$ height) and the herb layer $(<1 \mathrm{~m}$ height; Global models 2 and 3: Cov_Tilia_reg $\sim$ transect $*\left(\mathrm{~T}_{\mathrm{avg}}+\right.$ Prec $+\mathrm{M}+\mathrm{R}+\mathrm{N}+$ slope + aspect + ShareBeech + ShareOak + ShareLime $)$ ). All variables used in the global models showed a correlation with each other of $<0.7$. Global models were standardized using the function "standardize" (R package arm; [46]), 
to facilitate the interpretation of the relative strength of parameter estimates [47]. Then, we used the function "dredge" (R package MuMIn; [48]) to find those combinations of predictor variables that best explain the response variables. We considered all models with a $\triangle$ AICc $<2$ and applied the "model.avg" function of the MuMIN package to identify the most important predictors and their effects on the respective response variable using the zero method for averaging [47].

To assess the impact of T. tomentosa abundance in the canopy on understorey species richness (herb layer), we used a generalized additive model (GAM) to account for the non-linearity of the relationship (function "gam", package mgcv; species richness $\sim$ s(Cov_Tilia_TL); [49]). We investigated the relationship across the three study regions by accounting for the random effect of a different herb layer species richness among the three regions (extracting the random effect from the model lmer(species richness 1 I study area) and adjusting the species richness of each study area; R package lme4; [50]). We additionally fitted segmented regression models between species richness of the herb layer and canopy cover of T. tomentosa to identify potential breakpoints for species richness in response to T. tomentosa abundance (function "segmented" of the R package segmented [51]).

\subsubsection{Assessment of the Beech/Oak/Lime-Dataset}

Environmental characteristics and plot-based species richness values of beech, oak and lime forests were compared using one-way ANOVA with post-hoc Tukey-test for each study area. We considered the local abiotic factors as well as the climatic variables (see above). Additionally, we calculated the Ellenberg Quotient (EQ), which provides a rough characterization of the humidity of the climate and is defined as the mean temperature of the warmest month (July) divided by annual precipitation (Prec): EQ = 1000 ( $\mathrm{T}_{\mathrm{July}} /$ Prec). $E Q$ is interpreted to indicate a shift from absolute beech dominance $(E Q<20)$ to forests with dominant beech but with increasing admixture of other tree species including oak (EQ > 20-30) to mixed oak forests with or without beech (EQ > 30; [52]).

For contrasting species composition among forest types, we used non-metric multidimensional scaling with abundance values of species in the shrub and herb layer (function "metaMDS" of the package vegan based on Bray-Curtis-Dissimilarity with k= 3; [53]). To identify indicator species of the three forest types per study area, we used the function "multipatt" of the package indicspecies [54]. This function allows to identify indicator species for combinations of forest types [55]. We restricted the search for indicator species to the combination of two forest types.

Next to contrasting the plot-level species richness (=alpha diversity) among the three forest types, we also calculated gamma diversity of the forest types as the accumulated species richness across 10 plots per forest type (function "ChaoRichness" of the iNEXT package [56]. For this, we considered all species occurring in the shrub and herb layer and used a resampling approach to avoid effects of unequal sample sizes across forest types and study areas [57]. Thus, from the number of available plots per forest type and study area, we randomly drew 10 plots and calculated gamma diversity across these 10 plots. We repeated this 500 times with different combinations of plots. For each forest type and study area, a resampled number of 10 plots allowed for $>500$ unique plot combinations and thus 500 different gamma diversity calculations (for lime forests in Maciova and Eşelniţa only 11 and 12 different plots were available resulting in a lower number of unique combinations (10 out of 11 plots = 11 unique combinations for Maciova and 10 out of 12 plots = 66 unique combinations for Eşelniţa) and a smaller deviation in calculated gamma diversity values).

To investigate how forests with silver lime may complement or replace beech or oak forests for gamma diversity within wooded landscapes in the future, we created different landscape scenarios where beech and oak forests were successively replaced by lime forests in steps of $10 \%$. For this, we resampled 10 plots of the forest types in a way that all compositional combinations between beech and lime as well as oak and lime forests were represented in steps of $10 \%$ with 500 replications each, respectively (thus all combinations from $0 / 10$ to 10/10 lime forest plots; [57]). We additionally considered a scenario when 
beech is replaced by oak forests. For each simulated landscape, the gamma diversity was quantified per resampling using the accumulated species richness across resampled plots. We analysed the effect of simulated landscape composition on gamma diversity using generalized additive models with the function gam (gamma diversity $\sim$ (share lime plots)). We equally assessed the complementarity between beech and oak forests for each study area (gamma diversity $\mathrm{s}($ share oak plots)). All analyses were conducted using $\mathrm{R}$ version 3.6.6 (R Foundation for Statistical Computing, Vienna, Austria).).

\section{Results}

Tilia tomentosa was the dominant tree species in plots where T. tomentosa occurred in the tree layer in Milova (Table 1). In the other two study areas, the overall share of $T$. tomentosa was significantly lower. In Maciova, beech had the highest share of total tree layer cover in plots with $T$. tomentosa occurrence in the tree layer, while in Eşelniţa mesophytic oak was the dominant tree species in all plots with $T$. tomentosa occurrence. Tree and shrub layer species richness was similar among study sites in T. tomentosa plots. Herb layer species richness was higher in Eşelniţa (Table 1).

\subsection{Influencing Factors on the Canopy Cover of T. tomentosa}

Models included in the multi-model-averaging explained the variance in canopy cover of $T$. tomentosa by on average $25.5 \%$ (Table 2). As already shown in Table 1, local conditions in the study areas influenced the abundance of T. tomentosa in the tree layer with highest cover values found in Milova compared to the other two study areas. The interaction of study area with all abiotic factors remained within the best predictive models. However, the only detected significant effect was the decrease in the cover of T. tomentosa with an increasing soil reaction value in Milova. This trend also significantly differed from the other study areas.

Table 2. Results of multi-model-averaging investigating the effect of local abiotic and climatic factors on the cover of $T$. tomentosa in the tree layer $(>9 \mathrm{~m}$ height).

\begin{tabular}{|c|c|c|c|c|}
\hline & Estimate & SE & $z$-Value & $p$-Value \\
\hline (Intercept) Milova & $39.52 \mathrm{a}$ & 4.57 & 8.602 & $<0.001$ \\
\hline (Intercept) Maciova & $26.26 \mathrm{ab}$ & 8.26 & 3.161 & $<0.001$ \\
\hline (Intercept) Eşelniţa & $20.38 \mathrm{~b}$ & 3.63 & 5.583 & 0.001 \\
\hline \multicolumn{5}{|l|}{ Local abiotic factors } \\
\hline Soil reaction $x$ Milova & $-37.96 \mathrm{a}$ & 9.56 & 3.948 & $<0.001$ \\
\hline$x$ Maciova & $-7.58 b$ & 6.29 & 1.198 & 0.231 \\
\hline$x$ Eşelniţa & $9.95 \mathrm{~b}$ & 7.43 & 1.332 & 0.183 \\
\hline Nitrogen $x$ Milova & -5.01 & 10.41 & 0.480 & 0.631 \\
\hline$x$ Maciova & -3.21 & 8.02 & 0.399 & 0.690 \\
\hline$x$ Eşelniţa & -0.12 & 3.93 & 0.031 & 0.975 \\
\hline Moisture $x$ Milova & 2.52 & 10.26 & 0.246 & 0.806 \\
\hline$x$ Maciova & 1.76 & 7.36 & 0.238 & 0.812 \\
\hline$x$ Eşelniţa & -1.22 & 4.09 & 0.297 & 0.767 \\
\hline Aspect $x$ Milova & 0.20 & 1.84 & 0.110 & 0.912 \\
\hline$x$ Maciova & -0.76 & 3.53 & 0.214 & 0.830 \\
\hline$x$ Eşelniţa & 0.28 & 1.72 & 0.161 & 0.872 \\
\hline \multicolumn{5}{|l|}{ Climatic factors } \\
\hline $\mathrm{T}_{\mathrm{avg}} x$ Milova & -0.86 & 8.95 & 0.095 & 0.924 \\
\hline$x$ Maciova & 1.37 & 6.10 & 0.224 & 0.823 \\
\hline$x$ Eşelniţa & 2.89 & 4.65 & 0.620 & 0.535 \\
\hline Prec $x$ Milova & -0.73 & 5.80 & 0.126 & 0.900 \\
\hline$x$ Maciova & -1.81 & 9.93 & 0.181 & 0.856 \\
\hline$x$ Eşelniţa & -2.47 & 7.08 & 0.349 & 0.727 \\
\hline Mean $R^{2}$ & \multicolumn{4}{|c|}{$25.5 \pm 1.8 \mathrm{SD}(23.6-28.8)$} \\
\hline
\end{tabular}

Different letters show significant differences among study areas. Significant $p$-values are written in bold. 


\subsection{Influencing Factors on T. tomentosa Cover in the Understorey}

There was no effect of study area on $T$. tomentosa regeneration $>1 \mathrm{~m}$ height and the explanatory power of predictor variables was generally low (Table 3). We found a significant negative effect of the share of beech in the tree layer on T. tomentosa regeneration $>1 \mathrm{~m}$.

Table 3. Results of multi-model-averaging investigating the effect of local abiotic and climatic factors on the cover of $T$. tomentosa in the understorey.

\begin{tabular}{|c|c|c|c|c|}
\hline & Estimate & SE & $z$ Value & $p$-Value \\
\hline \multicolumn{5}{|c|}{ (a) Cover $T$. tomentosa in the shrub layer ( $>1 \mathrm{~m}<9 \mathrm{~m}$ height) } \\
\hline (Intercept) & 2.28 & 0.36 & 6.31 & $<0.001$ \\
\hline \multicolumn{5}{|l|}{ Local abiotic factors } \\
\hline Share Beech & -2.08 & 0.76 & 2.74 & 0.006 \\
\hline Species richness tree layer & -0.14 & 0.45 & 0.32 & 0.748 \\
\hline Nitrogen & -0.43 & 0.70 & 0.61 & 0.541 \\
\hline Soil reaction & -0.02 & 0.21 & 0.12 & 0.905 \\
\hline Moisture & -0.02 & 0.21 & 0.08 & 0.934 \\
\hline Aspect & 0.20 & 0.51 & 0.39 & 0.700 \\
\hline \multicolumn{5}{|l|}{ Climatic Factors } \\
\hline $\mathrm{T}_{\text {avg }}$ & -0.09 & 0.37 & 0.25 & 0.801 \\
\hline Mean $\mathrm{R}^{2}$ & \multicolumn{4}{|c|}{$5.8 \pm 0.6(5.0-6.6)$} \\
\hline \multicolumn{5}{|c|}{ (b) Cover T. tomentosa in the herb layer ( $\leq 1 \mathrm{~m}$ height) } \\
\hline (Intercept) Milova & 0.75 & 0.71 & 1.06 & 0.290 \\
\hline (Intercept) Maciova & 2.34 & 1.04 & 2.23 & 0.025 \\
\hline (Intercept) Eşelniţa & 1.34 & 0.58 & 2.28 & 0.022 \\
\hline \multicolumn{5}{|l|}{ Local abiotic factors } \\
\hline $\begin{array}{l}\text { Species richness tree layer } \\
\qquad \text { Milova }\end{array}$ & $0.36 \mathrm{a}$ & 0.98 & 0.37 & 0.711 \\
\hline$x$ Maciova & $4.76 \mathrm{~b}$ & 0.91 & 5.21 & $<0.001$ \\
\hline$x$ Eşelniţa & $-0.67 \mathrm{a}$ & 0.81 & 0.83 & 0.409 \\
\hline Total tree layer cover & -0.27 & 0.47 & 0.56 & 0.575 \\
\hline Share beech & -0.32 & 0.58 & 0.55 & 0.581 \\
\hline Slope & -0.03 & 0.19 & 0.16 & 0.877 \\
\hline Moisture $x$ Milova & 1.33 & 1.65 & 0.80 & 0.422 \\
\hline$x$ Maciova & 2.39 & 1.23 & 1.94 & 0.053 \\
\hline$x$ Eşelniţa & 1.96 & 0.94 & 2.07 & 0.039 \\
\hline Soil reaction & -0.03 & 0.18 & 0.15 & 0.880 \\
\hline \multicolumn{5}{|l|}{ Climatic factors } \\
\hline $\mathrm{T}_{\mathrm{avg}} \times$ Milova & $1.30 \mathrm{a}$ & 1.93 & 0.67 & 0.504 \\
\hline$x$ Maciova & $6.87 \mathrm{~b}$ & 1.86 & 3.66 & $<0.001$ \\
\hline$x$ Eşelniţa & $-0.02 \mathrm{a}$ & 0.84 & 0.02 & 0.982 \\
\hline Prec & -0.19 & 1.17 & 0.16 & 0.870 \\
\hline Mean $\mathrm{R}^{2}$ & & $26.1=$ & -28.1) & \\
\hline
\end{tabular}

Different letters show significant differences among study areas. Significant $p$-values are written in bold.

In contrast, the response of $T$. tomentosa regeneration in the herb layer $(<1 \mathrm{~m}$ height) to local abiotic factors and climatic factors partly depended on study area. The understorey regeneration of $T$. tomentosa in Maciova was positively influenced by canopy species richness and by temperature, while the respective variables had no effect in the other study areas. Consistent across study areas was a positive effect of the indicator value of moisture on regeneration abundance, though a significant effect was verified only for Eşelniţa (Table 3). Even though the mean annual temperature as climatic factor remained in all best predictive models, there was no significant and no consistent effect on $T$. tomentosa abundance in any of the investigated vegetation layers. 


\subsection{Effect of T. tomentosa Tree Cover on Understorey Species Richness across Regions}

There was a significant effect of $T$. tomentosa canopy cover on the herb layer species richness, though the explanatory power was low when accounting for the random effect of the study area $\left(R^{2}=6.8 \%, p=0.009\right.$ of the smooth term; Figure 1$)$. While at cover values $<40 \%$, species richness showed no response, numbers started to decrease at higher cover values of T. tomentosa (Figure 1). Segmented regression resulted in a significant breakpoint of $41.8 \pm 14.3 \%$ tree layer cover of $T$. tomentosa.

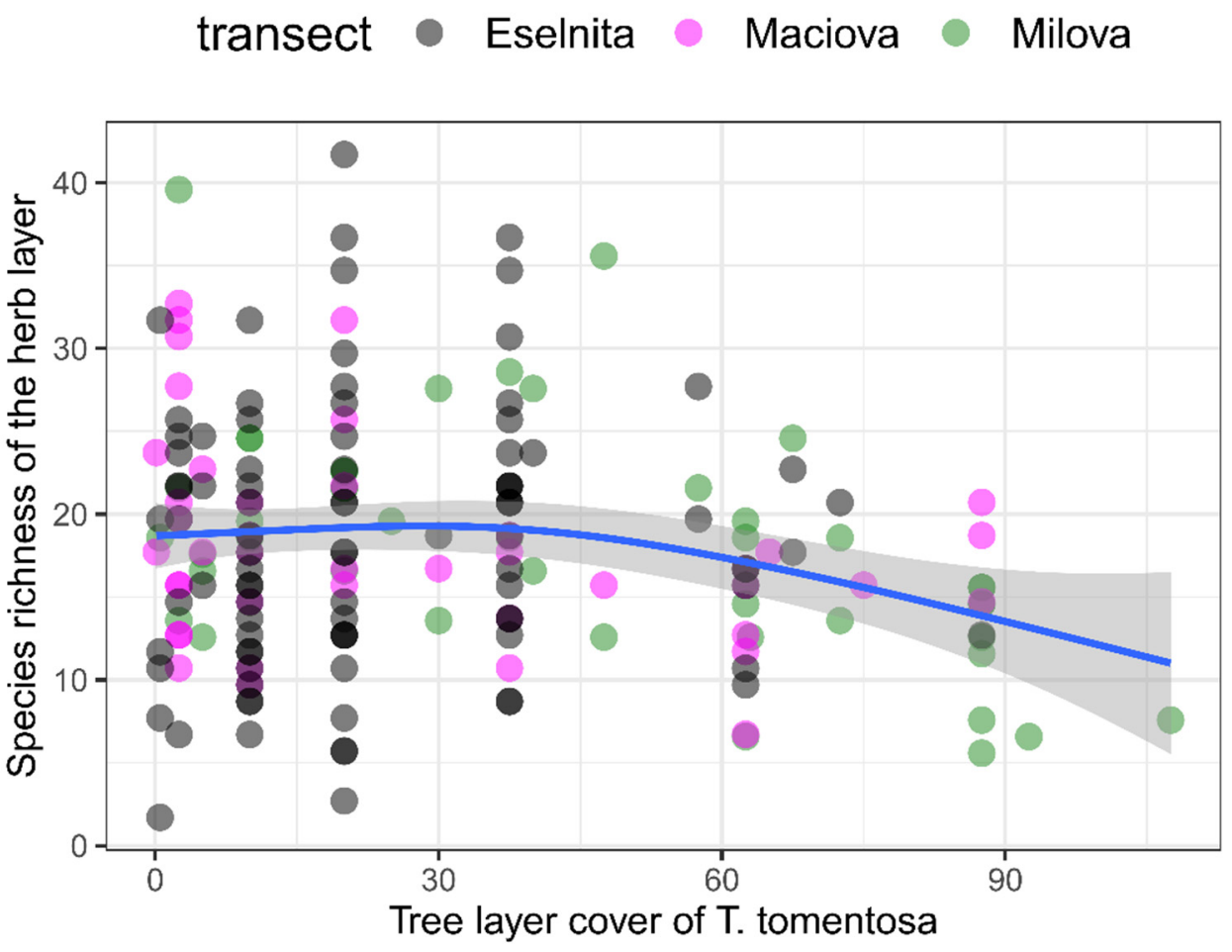

Figure 1. Species richness in relation to the canopy cover of T. tomentosa. The regression line shows the spline fitted curve based on a GAM model. The species richness accounts for the random effect of transect. Segmented linear regression resulted in a significant breakpoint at $41.8 \% \pm 14.3\left(R^{2}=6.8\right.$; $p=0.009$ (smooth term).

\subsection{Comparing Species Richness and Composition of Beech, Oak and Lime Forests}

Despite restricting the elevational range for the beech/oak/lime dataset, beech forests had the highest mean elevation, the highest indicator values for moisture and highest precipitation values (Table 4). $\mathrm{T}_{\text {avg }}$ was significantly higher in oak and lime forests compared to beech forests (Milova and Maciova). In Eşelniţa, mean temperature was highest in lime forests compared to the other forest types. For Milova and Maciova, the average EQ was in the range of mixed beech forests for all three forest types (EQ > 20-30) but was on average highest for the oak and lowest for beech forests with lime forests taking an intermediate position. For Eşelniţa, both lime and oak forests had an average EQ > 30 lying within the range of mixed oak forests. With on average 29.7, the EQ for the investigated beech forests was also close to the threshold defined by Ellenberg [52] for separating mixed beech from mixed oak forests. The beech forests in Eşelniţa were also characterized by a significantly lower aspect index indicating that these forests rather colonized slopes with lower energy input compared to oak and lime forests. While the lime forests in Milova and Maciova colonized intermediate temperature conditions between beech and oak forests, they showed on average highest mean temperature values in Eselnita. Except for Eşelniţa, beech forests showed a significantly higher nitrogen value compared to both other forest types. 


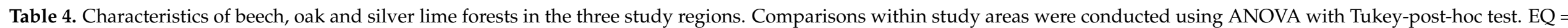
Ellenberg-Quotient.

\begin{tabular}{|c|c|c|c|c|c|c|c|c|c|}
\hline & Milova & & & Maciova & & & Eşelniţa & & \\
\hline & Beech & Oak & Lime & Beech & Oak & Lime & Beech & Oak & Lime \\
\hline$n$ & 22 & 21 & 22 & 40 & 17 & 11 & 50 & 31 & 12 \\
\hline \multicolumn{10}{|c|}{ Local abiotic factors } \\
\hline Moisture & $5.1 \pm 0.3 \mathrm{a}$ & $4.8 \pm 0.2 \mathrm{~b}$ & $4.8 \pm 0.2 b$ & $5.2 \pm 0.3 \mathrm{a}$ & $4.5 \pm 0.2 \mathrm{~b}$ & $4.9 \pm 0.2 c$ & $4.7 \pm 0.3 \mathrm{a}$ & $4.3 \pm 0.2 \mathrm{~b}$ & $4.1 \pm 0.2 \mathrm{~b}$ \\
\hline Nitrogen & $5.6 \pm 0.8 \mathrm{a}$ & $5.2 \pm 0.5 \mathrm{ab}$ & $5.0 \pm 0.5 \mathrm{~b}$ & $5.4 \pm 0.4 \mathrm{a}$ & $4.5 \pm 0.5 \mathrm{~b}$ & $4.9 \pm 0.4 \mathrm{c}$ & $4.7 \pm 0.7$ & $4.9 \pm 0.5$ & $4.9 \pm 0.5$ \\
\hline Soil reaction & $6.4 \pm 0.4$ & $6.4 \pm 0.3$ & $6.3 \pm 0.4$ & $6.2 \pm 0.4$ & $6.2 \pm 0.4$ & $6.1 \pm 0.7$ & $6.3 \pm 0.5 \mathrm{a}$ & $6.6 \pm 0.3 b$ & $6.7 \pm 0.2 b$ \\
\hline Slope $\left[{ }^{\circ}\right]$ & $12.6 \pm 8.6$ & $13.7 \pm 9.8$ & $15.2 \pm 9.0$ & $17.6 \pm 0.8$ & $20.0 \pm 9.5$ & $22.2 \pm 9.1$ & $16.0 \pm 9.8$ & $21.1 \pm 11.8$ & $21.7 \pm 8.6$ \\
\hline Aspect index & $6.5 \pm 2.2$ & $6.2 \pm 1.9$ & $5.5 \pm 2.6$ & $6.2 \pm 2.5$ & $7.5 \pm 1.5$ & $5.9 \pm 2.7$ & $5.1 \pm 2.3 \mathrm{a}$ & $7.4 \pm 1.4 \mathrm{~b}$ & $7.2 \pm 2.1 \mathrm{~b}$ \\
\hline \multicolumn{10}{|c|}{ Climatic factors } \\
\hline $\mathrm{T}_{\mathrm{avg}}\left[{ }^{\circ} \mathrm{C}\right]$ & $8.3 \pm 0.6 \mathrm{a}$ & $9.4 \pm 0.7 \mathrm{~b}$ & $9.4 \pm 0.6 \mathrm{~b}$ & $9.2 \pm 0.6 \mathrm{a}$ & $10.1 \pm 0.4 \mathrm{~b}$ & $9.7 \pm 0.4 \mathrm{~b}$ & $9.7 \pm 0.7 \mathrm{a}$ & $10.0 \pm 1.1 \mathrm{a}$ & $10.7 \pm 0.8 b$ \\
\hline Prec [mm] & $869.0 \pm 48.1 \mathrm{a}$ & $787.8 \pm 55.7 \mathrm{~b}$ & $786.9 \pm 48.5 \mathrm{~b}$ & $897.8 \pm 20.0$ a & $877.9 \pm 29.7 b$ & $888.41 \pm 3.0 \mathrm{ab}$ & $696.3 \pm 30.5 \mathrm{a}$ & $679.9 \pm 53.5 \mathrm{ab}$ & $652.2 \pm 38.7 \mathrm{~b}$ \\
\hline EQ & $21.8 \pm 2.2$ & $25.6 \pm 2.8$ & $25.5 \pm 2.3$ & $22.2 \pm 1.2 \mathrm{a}$ & $23.7 \pm 1.3 \mathrm{~b}$ & $23.0 \pm 0.8 \mathrm{ab}$ & $29.7 \pm 2.3 \mathrm{a}$ & $31.1 \pm 3.9 \mathrm{~b}$ & $33.4 \pm 3.3 \mathrm{~b}$ \\
\hline \multicolumn{10}{|c|}{ Canopy characteristics } \\
\hline $\begin{array}{c}\text { Total tree layer } \\
\text { cover [\%] }\end{array}$ & $93.1 \pm 23.6$ & $93.5 \pm 30.7$ & $94.7 \pm 20.1$ & $96.8 \pm 19.1$ & $90.2 \pm 20.5$ & $105.5 \pm 15.8$ & $89.5 \pm 18.0 \mathrm{a}$ & $86.2 \pm 21.7 \mathrm{a}$ & $104.9 \pm 22.2 b$ \\
\hline Mesophil. oak & $8.3 \pm 12.4 \mathrm{a}$ & $68.3 \pm 15.3 b$ & $11.5 \pm 14.4 \mathrm{a}$ & $2.4 \pm 7.5 \mathrm{a}$ & $75.6 \pm 15.1 \mathrm{~b}$ & $7.1 \pm 13.9 \mathrm{a}$ & $4.8 \pm 8.7 \mathrm{a}$ & $73.6 \pm 16.2 b$ & $22.3 \pm 15.2 c$ \\
\hline Thermophil. oak & 0 & $2.3 \pm 8.0$ & 0 & $0.5 \pm 2.5 \mathrm{a}$ & $6.7 \pm 13.4 \mathrm{~b}$ & $0 \mathrm{a}$ & 0 & $0.8 \pm 4.2$ & $0.1 \pm 0.2$ \\
\hline Silver lime & $2.9 \pm 8.1 \mathrm{a}$ & $7.5 \pm 11.9 \mathrm{a}$ & $78.0 \pm 17.9 \mathrm{~b}$ & $3.1 \pm 7.8 \mathrm{a}$ & $2.1 \pm 4.6 \mathrm{a}$ & $66.7 \pm 14.7 \mathrm{~b}$ & $7.5 \pm 9.9 \mathrm{a}$ & $12.6 \pm 12.5 \mathrm{a}$ & $62.9 \pm 17.2 b$ \\
\hline Hornbeam & $4.0 \pm 10.9 \mathrm{a}$ & $16.6 \pm 18.7 b$ & $3.8 \pm 7.8 \mathrm{a}$ & $3.8 \pm 8.8 \mathrm{a}$ & $8.3 \pm 12.4 \mathrm{ab}$ & $14.3 \pm 15.8 \mathrm{~b}$ & $0.3 \pm 1.0 \mathrm{a}$ & $1.1 \pm 3.5 \mathrm{ab}$ & $2.4 \pm 4.4 \mathrm{~b}$ \\
\hline \multicolumn{10}{|c|}{ Mean species richness per plot } \\
\hline Tree layer & $2.6 \pm 1.0$ & $3.2 \pm 1.3$ & $2.6 \pm 1.1$ & $2.9 \pm 1.4$ & $2.8 \pm 1.0$ & $2.9 \pm 0.9$ & $2.7 \pm 1.5$ & $2.9 \pm 1.1$ & $3.6 \pm 0.9$ \\
\hline Shrub layer & $1.6 \pm 1.7$ & $1.2 \pm 1.3$ & $1.7 \pm 1.5$ & $0.9 \pm 0.8 \mathrm{a}$ & $3.1 \pm 1.9 b$ & $1.3 \pm 0.9 \mathrm{a}$ & $1.0 \pm 0.8 \mathrm{a}$ & $2.8 \pm 1.4 \mathrm{~b}$ & $2.9 \pm 1.5 b$ \\
\hline Herb layer & $18.6 \pm 5.1 \mathrm{a}$ & $17.4 \pm 6.4 \mathrm{a}$ & $12.8 \pm 7.3 \mathrm{~b}$ & $12.5 \pm 4.8 \mathrm{a}$ & $22.0 \pm 8.1 b$ & $13.5 \pm 3.8 \mathrm{a}$ & $13.8 \pm 7.8 \mathrm{a}$ & $25.6 \pm 6.5 b$ & $22.2 \pm 5.4 \mathrm{~b}$ \\
\hline
\end{tabular}

Different letters mark significant differences among forest types. Highest values are bold when difference was significant. 
The canopy cover was dense in all three forest types due to a multi-layered canopy leading to accumulated tree layer cover values $>100 \%$ (Table 4). Lowest values were re-corded for beech and oak forests in Eşelniţa. By trend, lime forests had the highest accumulated tree layer cover in all three study areas. The difference was most pronounced and significant in Eşelniţa. The main tree species (beech/oak/lime) were dominant in the respective forest types. Lime forests in Milova and Eşelniţa were characterized by a slightly higher share of mesophytic oak than beech, while lime-rich forests in Maciova had a higher share of beech than oak.

Tree species diversity showed no significant difference among forest types across study areas. Species numbers in the shrub layer, though, were significantly highest in oak forests in Maciova and in oak and lime forests in Eşelniţa. Plot-based herb layer species richness was highest in beech and oak forests in Milova, in oak forests in Maciova and in oak and lime forests in Eşelniţa (Table 4).

NMDS ordination revealed a clear separation in species composition between beech and oak forests in all three study areas. Lime forests showed an overlap with oak forests in Milova and Eşelniţa, while their composition was intermediate between beech and oak forests but slightly more similar to beech forests in Maciova (Figure 2).

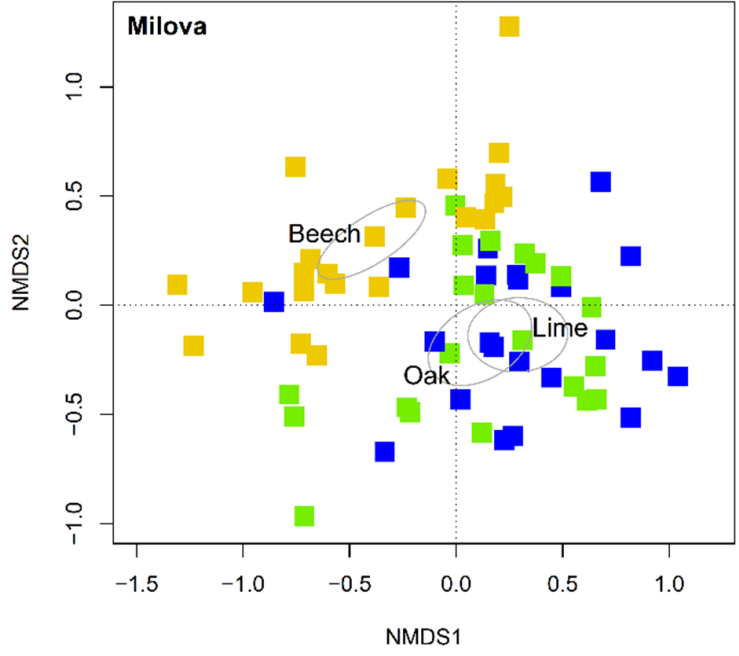

(a)

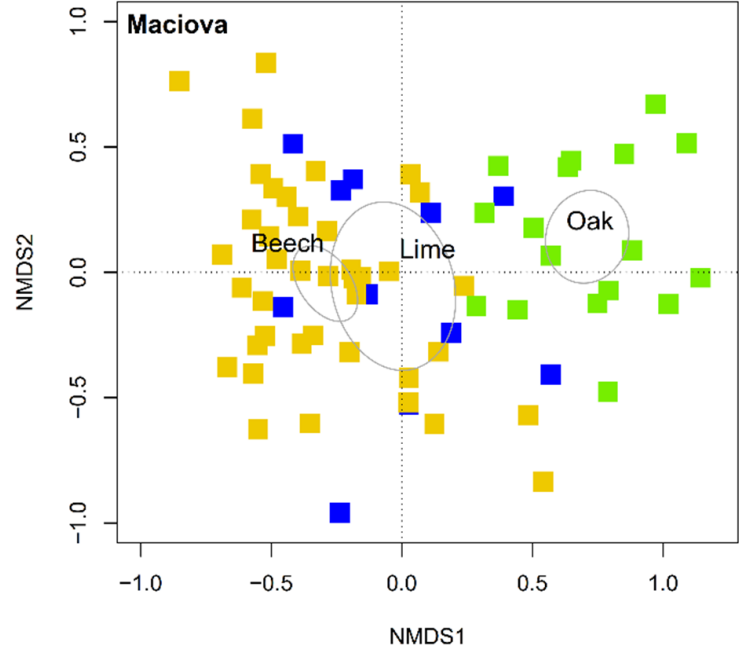

(b)

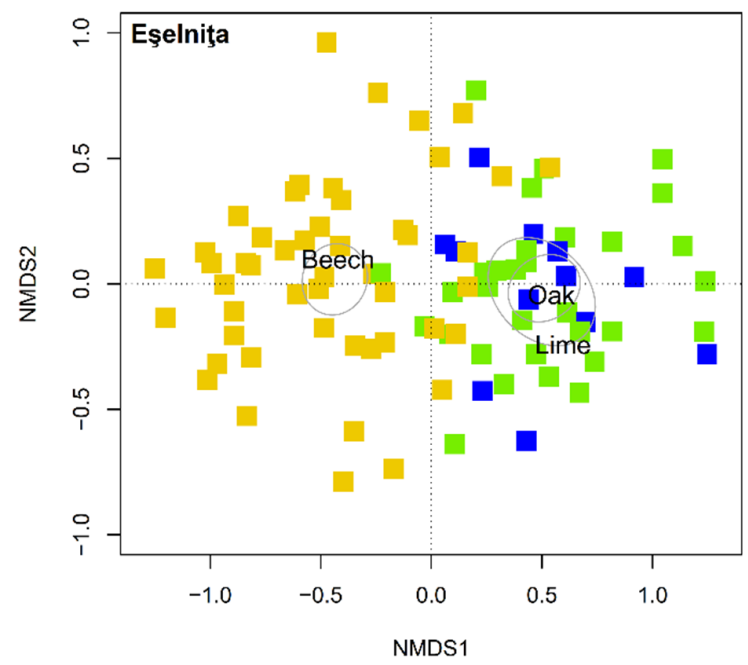

(c)

Figure 2. Ordination plots illustrating the different plant species compositions of the three forest types (orange $=$ beech, green $=$ oak, blue $=$ lime) and study areas. A non-metric multidimensional scaling (NMDS) was conducted based on Bray-Curtis dissimilarity (stress $=0.167$ for Milova (a), 0.162 for Maciova (b) and 0.145 for Eşelniţa (c)). The ellipses illustrate the standard error around the centroids. 


\subsection{Indicator Species of Beech, Oak and Lime Forests}

In total, 80 species were identified as indicators for the three forest types (Table A1). Twenty-two species were indicators in at least two study areas. Twenty of these 22 species were indicative for lime forests in at least one study area, the majority of these species in combination with oak forests (Table 5). Those species that were indicators for beech or beech and/or lime forests in the different study areas (four species) were on average characterized by lower light, temperature and continentality values but by higher moisture and nitrogen values compared to indicator species for oak or oak and lime forests (Table 5). Only the soil reaction value was similar across indicator groups. This pattern largely remained for all identified indicators (Table A1). Among indicators for beech and/or lime forests, some species (e.g., Urtica dioica, Sambucus nigra, Alliaria petiolata, Lamium maculatum) hint towards a higher degree of disturbance and mineralisation. Indicator species of lime and oak forests across study areas had a slightly higher T-value than exclusive indicators for oak forests (Table A1).

Table 5. Identified indicator species for the different forest types in the study areas. We restricted the search for indicators to species being indicative of a maximum of two forest types using the function "multipatt". All shown indicators were significant based on 999 permutations with $p<0.05$. Given are the Ellenberg indicator values (EIV) for light (L), temperature $(\mathrm{T})$, continentality $(\mathrm{C})$, moisture $(\mathrm{M})$, soil reaction $(\mathrm{R})$ and nitrogen $(\mathrm{N})$._sl = species in the shrub layer $(>1 \mathrm{~m}$ height). Shown are species that were indicators for at least two study areas. See Table A1 for all identified indicators.

\begin{tabular}{|c|c|c|c|c|c|c|c|c|c|}
\hline & \multirow[t]{2}{*}{ Milova } & \multirow[t]{2}{*}{ Maciova } & \multirow[t]{2}{*}{ Eşelniţa } & \multicolumn{6}{|c|}{ EIV } \\
\hline & & & & $\mathbf{L}$ & $\mathbf{T}$ & $\mathrm{C}$ & $\mathbf{M}$ & $\mathbf{R}$ & $\mathbf{N}$ \\
\hline \multicolumn{10}{|l|}{ Beech and/or oak } \\
\hline Dentaria bulbifera & Beech\&Oak & Beech & & 3 & 5 & 4 & 5 & 7 & 6 \\
\hline Galium schultesii & & Oak & Oak & 5 & 5 & 5 & 4 & 7 & 4 \\
\hline \multicolumn{10}{|l|}{ Beech \& Lime } \\
\hline Carex digitata & & Lime & Beech\&Oak & 3 & $x$ & 4 & 5 & $x$ & 4 \\
\hline Fagus sylvatica & Beech & Beech\&Lime & Beech & 2 & 5 & 3 & 6 & $\mathrm{x}$ & $\mathrm{x}$ \\
\hline Fagus sylvatica_sl & Beech & & Beech\&Lime & & & & & & \\
\hline Galium odoratum & Beech & Beech\&Lime & Beech & 2 & 5 & 2 & 5 & 6 & 5 \\
\hline \multirow{2}{*}{ Mercurialis perennis } & Beech & Beech\&Lime & & 3 & $x$ & 3 & 5 & 8 & 7 \\
\hline & & & $\varnothing$ EIV & 2.5 & 5.0 & 3.0 & 5.3 & 7.0 & 5.3 \\
\hline \multicolumn{10}{|l|}{ Oak \& Lime } \\
\hline Cornus mas_sl & Oak\&Lime & Oak\&Lime & Oak\&Lime & 6 & 7 & 4 & 4 & 8 & 4 \\
\hline Quercus petraea & Oak\&Lime & Oak\&Lime & Oak\&Lime & 6 & 5 & 2 & 4 & $x$ & $x$ \\
\hline Tilia tomentosa_sl & Oak\&Lime & Oak\&Lime & Oak\&Lime & 5 & 7 & 6 & 5 & 7 & 5 \\
\hline Poa nemoralis & & Oak\&Lime & Oak\&Lime & 5 & $x$ & 5 & 5 & 5 & 4 \\
\hline Prunus avium & Oak\&Lime & Oak\&Lime & & 5 & 5 & 4 & 5 & 7 & 5 \\
\hline $\begin{array}{l}\text { Brachypodium } \\
\text { sylvaticum }\end{array}$ & & Oak & Oak\&Lime & 3 & 5 & 3 & 5 & 6 & 6 \\
\hline Clinopodium vulgare & & Oak & Oak\&Lime & 7 & $x$ & 3 & 4 & 7 & 3 \\
\hline Dactylis glomerata & & Oak & Oak\&Lime & 6 & $x$ & 3 & 4 & $x$ & 6 \\
\hline Festuca heterophylla & & Oak & Oak\&Lime & 5 & 6 & 4 & 4 & 5 & 5 \\
\hline Fraxinus ornus_sl & & Oak & Oak\&Lime & 6 & 8 & 4 & 3 & 8 & 3 \\
\hline Lathyrus niger & & Oak & Oak\&Lime & 5 & 6 & 4 & 3 & 7 & 3 \\
\hline Lathyrus venetus & & Lime & Oak\&Lime & 3 & 7 & 6 & 4 & 8 & 4 \\
\hline Potentilla micrantha & Oak\&Lime & Oak & Oak\&Lime & 5 & 7 & 4 & 3 & 7 & 4 \\
\hline Rubus canescens & & Oak & Oak\&Lime & 7 & 7 & 5 & 3 & $x$ & 5 \\
\hline Sorbus torminalis & & Oak & Oak\&Lime & 5 & 7 & 4 & 3 & 7 & 4 \\
\hline \multirow[t]{2}{*}{ Verbascum glabratum } & & Lime & Oak\&Lime & 7 & 7 & 7 & 3 & 7 & $x$ \\
\hline & & & $\varnothing$ EIV & 5.4 & 6.5 & 4.3 & 3.9 & 6.8 & 4.4 \\
\hline
\end{tabular}




\subsection{Gamma-Diversity of Lime, Oak and Beech Forests and Their Combinations}

We detected different gamma diversity patterns across the three study areas and forest types. In Milova, forests dominated by beech or oak were significantly more diverse than those dominated by silver lime (Figure $3 a, b$ ). Maximum gamma diversity was reached when combining $90 \%$ of beech forests and $10 \%$ lime forests with diversity significantly decreasing at a share of $40 \%$ lime forests. Beech and oak forests also showed a small complementarity (maximum diversity at $60 \%$ beech plots) but there was no significant difference between this maximum gamma diversity and the minimum at $100 \%$ oak plots.

For Maciova, oak forests were most diverse. There was a steep and significant decline when oak forest plots were replaced by lime plots, while replacing beech by oak forests increased gamma diversity up to reaching a $70 \%$ oak forest share in a simulated landscape. For both scenarios, a maximum diversity was reached with $90 \%$ oak forests within simulated landscapes. When replacing beech by lime forests, gamma diversity only showed a weak response $\left(R^{2}=0.023\right)$ indicating similar species assemblages in both forest types.

In Eşelniţa, beech forests were least diverse. Lime forests significantly increased gamma diversity in simulated beech forest landscapes, though gamma diversity values remained almost similar when lime forests reached a share of $80 \%$. The maximum gamma diversity was, however, reached in oak forests. The gamma diversity linearly decreased when replacing oak by lime forest plots but with no significant difference in gamma diversity between $100 \%$ oak and $100 \%$ lime.

Across the study areas, there was a consistent reduction in gamma diversity when oak forests were replaced by lime forests, though in different magnitudes. The response of replacing beech by lime forests was site-dependent with decreasing gamma diversity in Milova, equal species numbers in Maciova and increasing gamma diversity in Eşelniţa. 
Beech vs. Lime

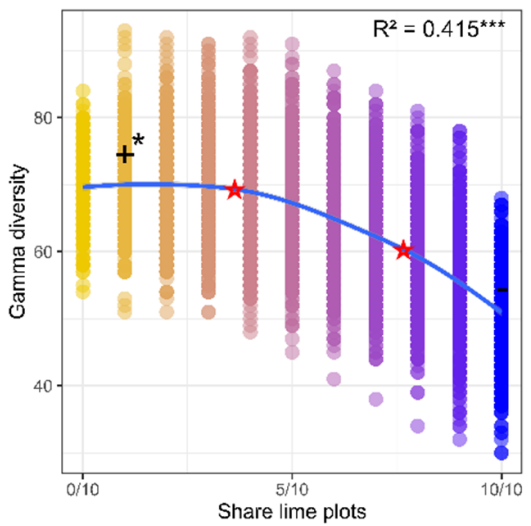

(a)

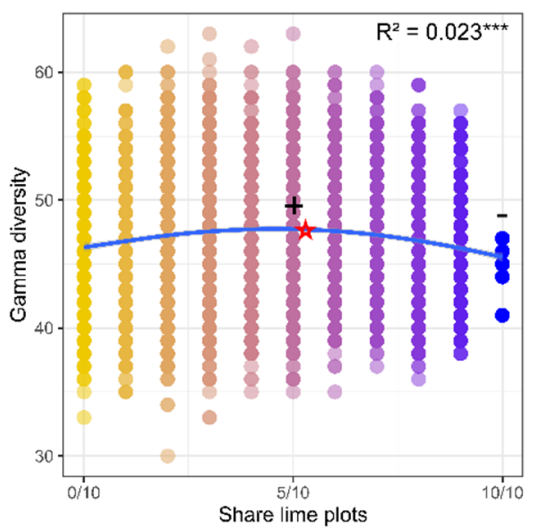

(d)

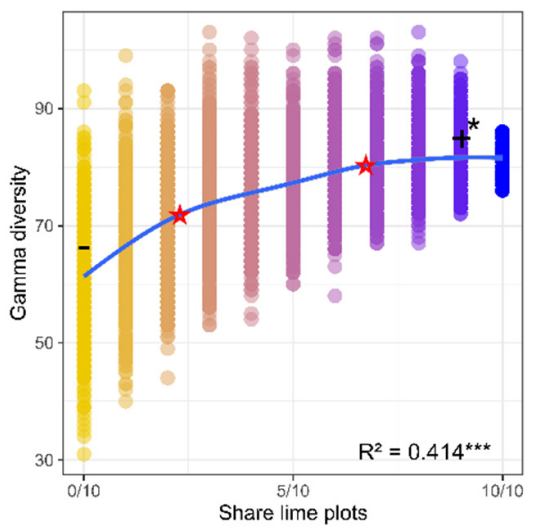

(g)
Oak vs. Lime

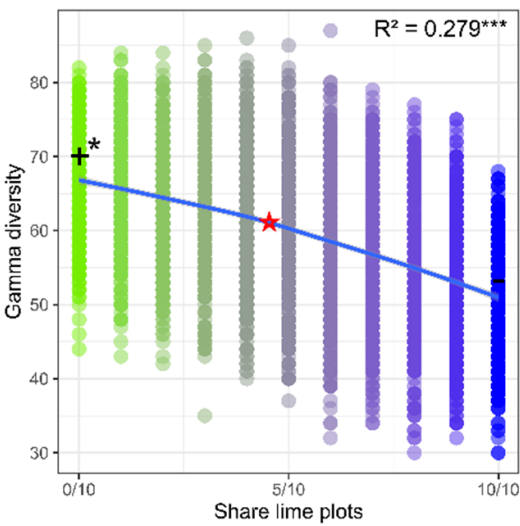

(b)

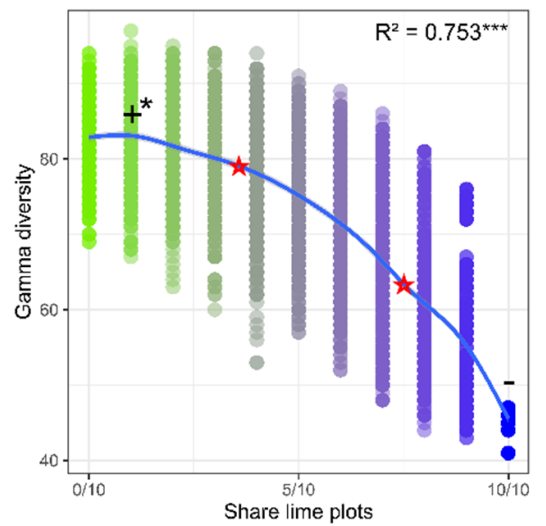

(e)

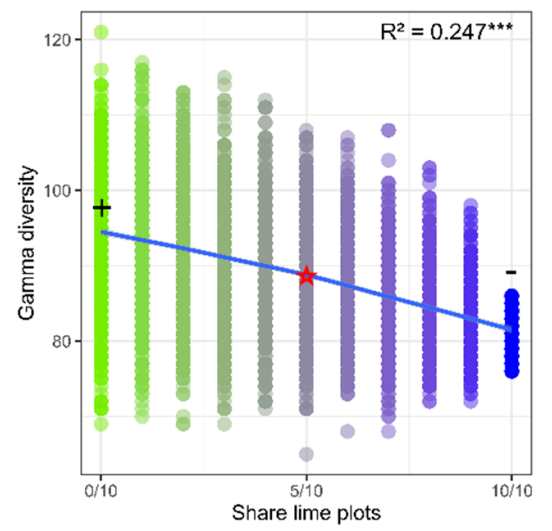

(h)
Oak vs. Beech

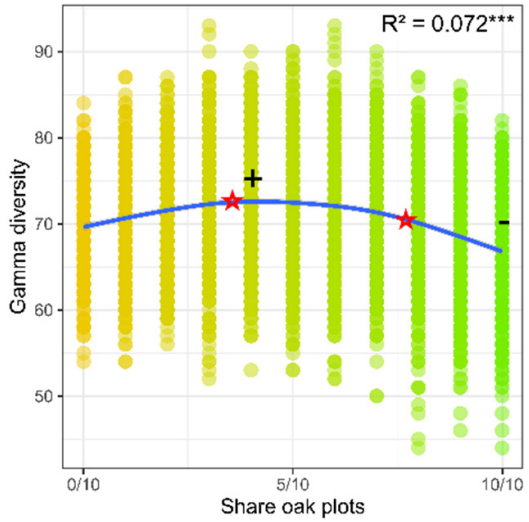

(c)

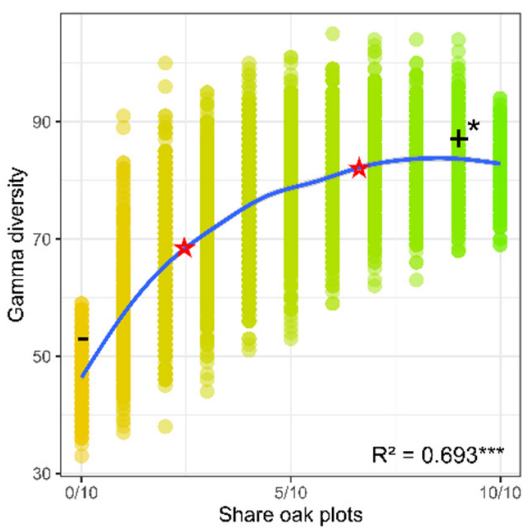

(f)

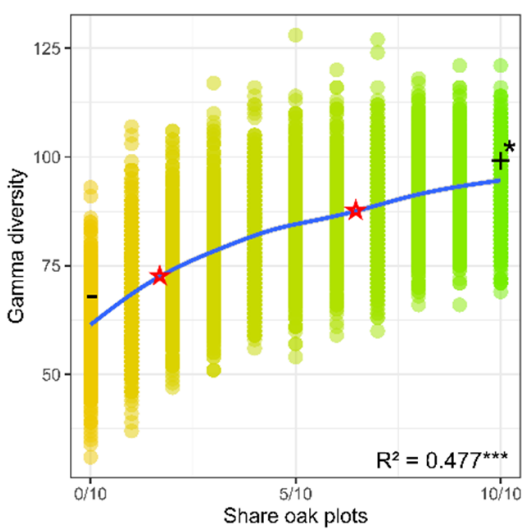

(i)

Figure 3. Gamma diversity of simulated forest landscapes composed of different shares of two forest types for the study areas Milova (a-c), Maciova ( $\mathbf{d}-\mathbf{f})$ and Eşelniţa $(\mathbf{g}-\mathbf{i})$. Simulated landscapes were created by randomly sampling 10 plots in a way that all compositional combinations of forest types were presented in steps of $10 \%$. (a,d,g): Beech plots were replaced by lime plots; (b,e,h): Oak plots were replaced by lime plots; (c,f,i): Beech plots were replaced by oak plots. Each combination of $0 / 10$ to $10 / 10$ was repeated up to 500 times. Points represent the repetitions, + gives the maximum average gamma diversity value across repetitions, - gives the minimum gamma diversity, * indicates a significant difference between maximum and minimum gamma diversity. The blue line represents the spline fitted curve of the GAM model. Red stars represent significant breakpoints of segmented linear regressions. Note the varying scale of the $y$-axis to have a better visualization of complementarity patterns between forest types. ${ }^{* * *} p<0.001$. 


\section{Discussion}

Our study shows the potential for an ecological integration of Tilia tomentosa into forest landscapes of Central Europe currently dominated by European beech. While the species composition of forests dominated by silver lime was similar to mesophytic oak forests in two study areas of western Romania with harbouring also thermophilous species (e.g., Potentilla micrantha, Lathyrus venetus, Scutellaria altissima), lime forests were also habitat for mesothermic and mesophilous species. These species benefit from the dense canopy of silver lime and are classified as Fagetalia species in Central Europe (e.g., Galium odoratum, Lamiastrum galeobdolon, Mercurialis perennis). Silver lime forests may therefore function in two different ways dependent on the establishment site: (i) they can link beech- and oak-dominated forests and provide habitat for species of both forest types under moderate to high climatic humidity. (ii) With decreasing humidity, lime-dominated forests may form a link to thermophilous oak forest communities and can by this expand the range of mesothermic and mesophilous species. Under decreasing climatic humidity, our results show that lime forests may have the potential to increase the regional diversity of beech forest landscapes in the future.

\subsection{Local Site Factors Determine the Abundance of T. tomentosa}

The abundance of $T$. tomentos $a$ in the tree and regeneration layer was rather dependent on local site conditions, including site specific forest management, than on climatic conditions. We assume that the different disturbance histories and frequencies observed in the three study areas played a role in shaping the local distribution patterns of $T$. tomentosa along the elevational transects. Forest fires and clear-cutting promoted the establishment of silver lime. Repeated coppicing, particularly in Milova, also increased the tree species abundance in former times. An expansion of silver lime following forest management was also observed by Dinić et al. [29] on the Fruška Gora mountain in Serbia. Here T. tomentosa expanded in mesophilous sessile oak-hornbeam stands. In western Romania, lime-dominated stands were generally characterized by a high deadwood proportion of Populus tremula, Betula pendula and Prunus avium indicating the former pioneer character of these sites [36]. These pioneer species have presumably been outcompeted by silver lime or have been removed by management. In addition, among the few species that were found to be indicators for lime forests (Table A1), some nitrophilous species such as Alliaria petiolata and Lamium maculatum also indicate an impact of disturbance e.g., due to repeated and ongoing forest management.

Within the study areas, no uniform local factor could be identified that promoted or decreased the abundance of $T$. tomentosa in the tree layer. For Milova, the cover in the tree layer increased with decreasing soil reaction. According to literature, T. tomentosa grows on slightly acidic to neutral soils as found for the three transects $[18,20]$. The negative effect may coincide with the loss of light-demanding species from the understorey that are also indicative of a high soil reaction.

In the herb layer, the cover of T. tomentosa was promoted by soil moisture. This supports the general finding that silver lime is mainly found on deep loamy soils with a good water holding capacity and that soil moisture limits the natural occurrence of $T$. tomentosa $[18,19]$. The positive significant effect of soil moisture found in Eşelniţa (and marginally non-significant in Maciova, Table 3), the study site with highest temperatures, lowest precipitation values and highest EQ indicates that soil moisture may become more important for the establishment of T. tomentosa in the future under a changing climate in its native range.

Beech was the dominant tree species in plots with $T$. tomentosa in the tree layer of Maciova. Though total canopy cover and the share of beech had no significant negative effect on the cover of $T$. tomentosa in the herb layer, a positive effect of tree species richness and temperature may indicate the influence of a lower competitive strength of beech. A higher tree species diversity can also reduce the homogeneous shading of dominant beech trees and may allow a higher light transmittance to the forest floor and a larger 
heterogeneity of light conditions, particularly due to a different timing of leaf expansion [45]. An impact of competitive beech on the regeneration of silver lime is supported by a negative relationship between lime regeneration $>1 \mathrm{~m}$ and the share of beech in the canopy. However, abundance of $T$. tomentosa in the shrub layer was in general not well explained by the investigated local abiotic and climatic factors, indicating that unexplored factors such as game browsing may limit the growth of seedlings [58].

Our investigations in the natural beech-oak ecotone underline the importance of local conditions shaped by natural disturbance and forest management. Larger scale disturbances seem to allow $T$. tomentosa to become dominant in the canopy particularly on neutral soils under humid conditions. The good resprouting ability may represent a competitive advantage over beech for recolonizing disturbed forests sites in Central Europe. For a successful growing up from the herb to the shrub layer, though, other limiting factors such as browsing intensity should be considered as well. In addition, soil moisture and water holding capacity may become more important for the establishment in the future, both in Central Europe and in the native range, with decreasing climatic humidity and an increasing drought frequency. Dendrochronological data from the studied beech and lime forests in western Romania show that $T$. tomentosa is similarly sensitive to an increase in climate aridity with climate warming as is beech in the ecotone to oak forests, with both species revealing continued growth declines during the last 20 years (Kasper et al., unpublished results). This points to moderate drought sensitivity of lime, in contrast to the rather insensitive mesic and thermophilous oak species of the study region.

\subsection{The Effect of Lime on Plant Species Diversity and Composition}

T. tomentosa had a neutral effect on plot-based plant species richness up to a canopy cover of ca. $40 \%$ indicating its suitability as an admixed tree species. In mixture, the good litter quality and rapid litter decomposition of T. tomentosa $[18,20,59]$, as also found for other lime species [60,61], contributes to soil quality and even to species richness [62]. Above a canopy cover of ca. $40 \%$, as a potential result of frequent disturbances and forest management, plot-based species richness decreased presumably due to limited light availability preventing the establishment of a herb and shrub layer [63]. Here, lime seems to function like European beech in Central Europe that can lead to a reduction in understorey plant species diversity with increasing abundance [62,64]. Even though we found no difference in total canopy cover between forest types or an effect of lime cover on mean light indicator values per plot (data not shown), light seems to be an important factor for reducing species richness when lime expands its tree cover. The indicator species identified for lime forests in western Romania (in combination with beech or oak forests) showed on average slightly lower light indicator values than indicators for beech or oak forests alone (Table A1).

Lime-dominated forests were particularly species-poor in Milova and Maciova both for alpha diversity at the plot level and for forest type gamma diversity. Under the relatively humid conditions, silver lime was either dominant itself (Milova) or was associated with competitive beech and hornbeam (Maciova) that are known to produce shady conditions under the canopy [65]. With increasing EQ in lime forests (Maciova < Milova < Eşelniţa), gamma diversity on the other hand increased in this forest type. Thus, under optimized climatic conditions for beech (average EQ in Milova $=21.8$ for beech forests), lime forests may decrease the regional diversity of forest landscapes under scenarios establishing lime at the expense of beech forests. With decreasing climate humidity, replacing beech by lime forests can either keep gamma diversity of forest landscapes constant (Maciova) or can increase it (Eşelniţa) and may therefore be considered an option for the future. Thereby, silver lime may be able to expand the range of typical species of the order Fagetalia in Central Europe such as Galium odoratum, Mercurialis perennis or Lamiastrum galeobdolon. These species may benefit from a dense canopy and from moist forest microclimate conditions within lime forests. On the other hand, lime forests in Milova and Eşelniţa rather resembled mesophytic oak forests of Carpinetalia betuli and showed transitions to thermophilous 
communities with species of the order Quercetalia pubescenti-petraeae (e.g., Cornus mas, Lathyrus niger, L. venetus, Sorbus torminalis) underscoring their transitional function toward thermophilic conditions.

However, the lime forests in all three study areas were less species rich in terms of alpha and gamma diversity than oak forests (though for Eşelniţa not significantly). This shows the importance of oak forests for biodiversity and a potential negative effect of lime on this biodiversity. Chudomelová et al. [66] for example demonstrated the impact of an expansion of Tilia cordata into steppic oak forests in the Czech Republic. A reduced light availability led to a loss of many typical oak forest and open land species. Similarly, Mölder et al. [67] showed how an expansion of beech reduced herb layer diversity in mixed broadleaved forests due to a reduction in light transmittance indicating some similarities for both tree species when it comes to impacts on forest biodiversity. In addition, species numbers of herbivorous insects [68] and saproxylic beetles [69] detected for the genus Tilia are rather similar (in fact slightly lower) to species numbers of beech but much lower compared to oak, even though all tree species have some specialized herbivores.

Thus, an introduction of silver lime cannot compensate for the potential loss of all native tree species in the future, in particular not for native oak species. It can, however, maintain functions of beech forests under a changing climate by providing a dense canopy and a moist forest microclimate and by allowing mesophilous and mesothermic woodland plant species to occur in warmer forest landscapes. This functionality of silver lime also reflects its ecological range in the native distribution area being associated with meso- to thermophilous oak species $[18,20,26,28,29]$ and with European beech [24,25].

\subsection{Limitations of the Study}

For our study, we used three elevational gradients for simulating the effect of climatic change on plant species richness and composition. Apart from general patterns, our results reveal site-specific effects that are difficult to quantify and to evaluate. A high proportion of accompanying pioneer tree species among recorded deadwood items in lime forests [36] and the occurrence of disturbance indicators in the understorey indicate an impact of former and ongoing disturbance on the establishment of lime forests that is largely driven by local conditions and by chance. The current distribution of lime forests along the transects may therefore not all reflect the most suitable sites for this tree species. On the other hand, the importance of disturbance history for the establishment of T. tomentosa identifies disturbed sites as potential establishment areas in the future in Central Europe and a competitive advantage compared to other tree species. However, more research is needed on the species' future growth potential in Central Europe under different climatic and soil conditions [15].

Forest management and recent disturbances can locally mask the impact of tree species on plant species richness and composition. In contrast to the other study sites, beech forests in Milova showed similar species numbers compared to oak forests, while in the other areas oak forests were most diverse. With indicators such as Urtica dioica and Sambucus nigra (Table A1), the beech forests in Milova were characterized by some nitrophilous species that indicate disturbances with positive effects on plant species diversity. In addition, the distribution of oak forests may have been promoted by the local people in the past for example due to wood pasture. The climatic humidity for the Maciova transect, for example, seems suitable for beech (mixed) forests with EQ values $<25$ also in plots with oak and lime dominance. Here the oak forests showed a slightly higher aspect index indicating a promotion due to favourable mesoclimatic conditions under anthropogenic influence.

\section{Conclusions}

Our results from a natural beech-oak ecotone on the south-eastern edge of Central Europe, where T. tomentosa is a native forest tree, indicate that an establishment of silver lime can be successful on deep neutral soils with a relatively good water holding capacity if the competitive strength of beech is reduced e.g., after disturbances. Up to a tree cover of 
$40 \%$, silver lime showed no effect on plot-level plant species richness showing its potential as an admixed tree species. When dominant, alpha-diversity of the herb layer was reduced. In general, lime forests were characterized by a lower alpha and gamma diversity of plant species compared to oak forests. Particularly for shade tolerant species, however, the dense canopy of lime forests can maintain habitats for mesophilous and mesothermic species and can extend their range into warmer landscapes. At the same time, lime forests provide habitat for thermophilous species when climatic humidity decreases.

Based on our results, silver lime may be regarded as suitable for future silviculture in Central Europe with a potential particularly as an admixed species. Noteworthy are its beneficial effects on ecosystem services, e.g., ameliorated soil properties [18], forest microclimate [63], ecosystem resilience, post-disturbance recovery of forest carbon [20], latesummer nutrient-source to pollinators [31], and its relatively low potential for invasiveness and hybridization [19]. Considering the presence of T. tomentosa in Central Europe in the last interglacial [21,22], assisted migration measures would support the potential re-expansion of this tree species from south-east to northern Central Europe. Nevertheless, a potential introduction is unadvisable close to protected areas left for natural development [70] and in open oak forests [66] to avoid unwanted forest habitat and biodiversity changes. In addition, decreased growth responses in recent years detected in western Romania, the availability of only few establishment trials in Central Europe until now [15], and the risk of being exposed to unsuitable conditions in the introduced range (e.g., late frost, [71]) that have not been explored yet, underline the need for more research with this and other thermophilous tree species. The uncertainties of a non-native species also underline the importance of focusing on native tree species in Central Europe and their functionality under changing climatic conditions such as native Tilia species [60,61], Acer campestre or Sorbus species [72] that may be better adapted to future climatic conditions than the current main timber species.

Author Contributions: Conceptualization, S.H. and H.W.; methodology, data curation and data analysis, S.H., V.Ö., A.I.; data collection, V.Ö. and A.I.; writing-original draft preparation, S.H.; writing - review and editing, V.Ö., A.I., E.B., C.L., H.W., S.H.; project administration, H.W., E.B., C.L.; funding acquisition, H.W., E.B., C.L. All authors have read and agreed to the published version of the manuscript.

Funding: This work was conducted in the frame of the NEMKLIM project: Nemoral Forests under Climate Extremes (NEMKLIM Project, grant number 3517861300), financed by the German Federal Agency for Nature Conservation (Bundesamt für Naturschutz, BfN) and the German Federal Ministry for the Environment, Nature Conservation and Nuclear Safety, Germany.

Institutional Review Board Statement: Not applicable.

Informed Consent Statement: Not applicable.

Data Availability Statement: The data presented in this study are available on request from the corresponding author.

Acknowledgments: We are grateful to the local authorities for their support of the project and to several supporting students of the HAWK for their help during field work. We thank A. M. Petriţan for her general support of the project and the provision of details on forest management, P. Schall for assistance with statistical questions, and two reviewers for the helpful suggestions to improve the manuscript.

Conflicts of Interest: The authors declare no conflict of interest. The funders had no role in the design of the study; in the collection, analyses, or interpretation of data; in the writing of the manuscript, or in the decision to publish the results. 


\section{Appendix A}

Table A1. Identified indicator species for the different forest types in the three study areas. We restricted the search for indicators to species being indicative of a maximum of two forest types using the function "multipatt". All indicators were significant based on 999 permutations with $p<0.05$. Given are the Ellenberg indicator values (EIV) for light (L), temperature (T), continentality (C), moisture (M), soil reaction (R) and nitrogen $(\mathrm{N})$._sl = species in the shrub layer ( $>1 \mathrm{~m}$ height).

\begin{tabular}{|c|c|c|c|c|c|c|c|c|c|c|}
\hline & Milova & Maciova & Eşelniţa & & $\mathbf{L}$ & $\mathbf{T}$ & $\mathrm{C}$ & $\mathbf{M}$ & $\mathbf{R}$ & $\mathbf{N}$ \\
\hline \multicolumn{11}{|l|}{ Beech } \\
\hline Acer platanoides_sl & Beech & & & & 4 & 6 & 4 & 5 & $x$ & $x$ \\
\hline Acer pseudoplatañus & Beech & & & & 3 & $x$ & 4 & 6 & $x$ & 7 \\
\hline Acer pseudoplatanus_sl & Beech & & & & & & & & & \\
\hline Circaea lutetiana & Beech & & & & 4 & 5 & 3 & 7 & 7 & 7 \\
\hline Dentaria glandulosa & Beech & & & & 2 & 4 & 6 & 6 & 7 & 8 \\
\hline Lathyrus hallersteinii & Beech & & & & 5 & 5 & 6 & 5 & 6 & $x$ \\
\hline Sambucus nigra & Beech & & & & 6 & 5 & 3 & 6 & $x$ & 9 \\
\hline Populus tremula & & & Beech & & 6 & 5 & 5 & 5 & $x$ & $x$ \\
\hline Tilia cordata & Beech & & & & 5 & 5 & 4 & 4 & $x$ & 5 \\
\hline \multirow{2}{*}{ Urtica dioica } & Beech & & & & $x$ & $x$ & $\mathrm{x}$ & 6 & 7 & 9 \\
\hline & & & & $\varnothing$ & 4.4 & 5.0 & 4.4 & 5.6 & 6.8 & 7.5 \\
\hline \multicolumn{11}{|l|}{ Beech \& oak } \\
\hline Dentaria bulbifera & Beech\&Oak & Beech & & & 3 & 5 & 4 & 5 & 7 & 6 \\
\hline \multicolumn{11}{|l|}{ Beech \& Lime } \\
\hline Fagus sylvatica & Beech & Beech\&Lime & Beech & & 2 & 5 & 3 & 6 & $x$ & $x$ \\
\hline Fagus sylvatica_sl & Beech & & Beech\&Lime & & & & & & & \\
\hline Galium odoratum & Beech & Beech\&Lime & Beech & & 2 & 5 & 2 & 5 & 6 & 5 \\
\hline Lamiastrum galeobdolon agg. & & Beech\&Lime & & & 2 & 5 & 4 & 5 & 7 & 5 \\
\hline Mercurialis perennis & Beech & Beech\&Lime & & & 3 & $\mathrm{x}$ & 3 & 5 & 8 & 7 \\
\hline Carex digitata & & Lime & Beech\&Oak & & 3 & $x$ & 4 & 5 & $\mathrm{x}$ & 4 \\
\hline \multirow[t]{2}{*}{ Ulmus glabra } & & Beech\&Lime & & & 4 & $\hat{5}$ & 3 & 5 & $\hat{7}$ & 7 \\
\hline & & & & $\varnothing$ & 2.7 & 5.0 & 3.2 & 5.2 & 7.0 & 5.6 \\
\hline \multicolumn{11}{|l|}{ Oak } \\
\hline Ajuga reptans & & & Oak & & 6 & $x$ & 2 & 5 & 6 & 6 \\
\hline Buglossoides purpurocaerulea & & & Oak & & 5 & 7 & 4 & 4 & 7 & 4 \\
\hline Calamagrostis arundinacea & & Oak & & & 6 & 5 & 4 & 5 & 4 & 5 \\
\hline Campanula persicifolia & & Oak & & & 6 & 5 & 4 & 4 & 8 & 3 \\
\hline Carex caryophyllea & & Oak & & & 7 & $x$ & 3 & 4 & $\mathrm{x}$ & 2 \\
\hline Carpinus betulus_sl & & Oak & & & 3 & 5 & 4 & 5 & $x$ & $x$ \\
\hline Cephalanthera longifolia & & Oak & & & 5 & 5 & 3 & 4 & 6 & 4 \\
\hline Chamaecytisus leiocarpus & & Oak & & & 8 & 5 & 6 & 3 & 8 & $x$ \\
\hline Crataegus monogyna & & Oak & & & 7 & 5 & 3 & 4 & 8 & 4 \\
\hline \multicolumn{11}{|l|}{ Crataegus monogyna_sl } \\
\hline Cruciata glabra & & Oak & & & 6 & 5 & 4 & 5 & 7 & 5 \\
\hline Fragaria vesca & & Oak & & & 6 & $x$ & 5 & 5 & $x$ & 6 \\
\hline Galium schultesii & & Oak & Oak & & 5 & 5 & 5 & 4 & 7 & 4 \\
\hline Genista tinctoria & & Oak & & & 7 & 5 & 5 & 4 & 5 & 2 \\
\hline Hieracium sabaudum & & Oak & & & 5 & 6 & 3 & 4 & 4 & 2 \\
\hline Lapsana communis & & & Oak & & 5 & 6 & 3 & 5 & $x$ & 7 \\
\hline Lunaria annua & & & Oak & & 4 & 6 & 6 & 6 & 7 & 8 \\
\hline Melica nutans & & Oak & & & 3 & $x$ & 3 & 4 & $x$ & 3 \\
\hline Melittis melissophyllum & & Oak & & & 5 & 7 & 2 & 4 & 6 & 3 \\
\hline Mycelis muralis & Oak & & & & 3 & 5 & 2 & 5 & $\mathrm{x}$ & 6 \\
\hline Quercus cerris & & Oak & & & 7 & 8 & 4 & 3 & 6 & $x$ \\
\hline Quercus frainetto & & Oak & & & 7 & 8 & 6 & 3 & 7 & $x$ \\
\hline Rosa arvensis & & Oak & & & 5 & 6 & 2 & 5 & 7 & 5 \\
\hline Rosa canina & & Oak & & & 7 & 5 & 3 & 4 & $\mathrm{x}$ & $x$ \\
\hline Solidago virgaurea & & Oak & & & 6 & $x$ & $x$ & 5 & $x$ & 4 \\
\hline Sorbus torminalis_sl & & Oak & & & 5 & 7 & 4 & 3 & 7 & 4 \\
\hline Symphytum tuberosum & Oak & & & & 4 & $x$ & 4 & 5 & 6 & 5 \\
\hline Trifolium medium & & Oak & Oak & & 7 & $\hat{6}$ & 4 & 4 & 6 & 3 \\
\hline \multirow[t]{2}{*}{ Veronica chamaedrys } & & Oak & & & 6 & $\mathrm{x}$ & $\mathrm{x}$ & 4 & 7 & $\mathrm{x}$ \\
\hline & & & & $\varnothing$ & 5.6 & 5.8 & 3.8 & 4.3 & 6.5 & 4.3 \\
\hline
\end{tabular}


Table A1. Cont.

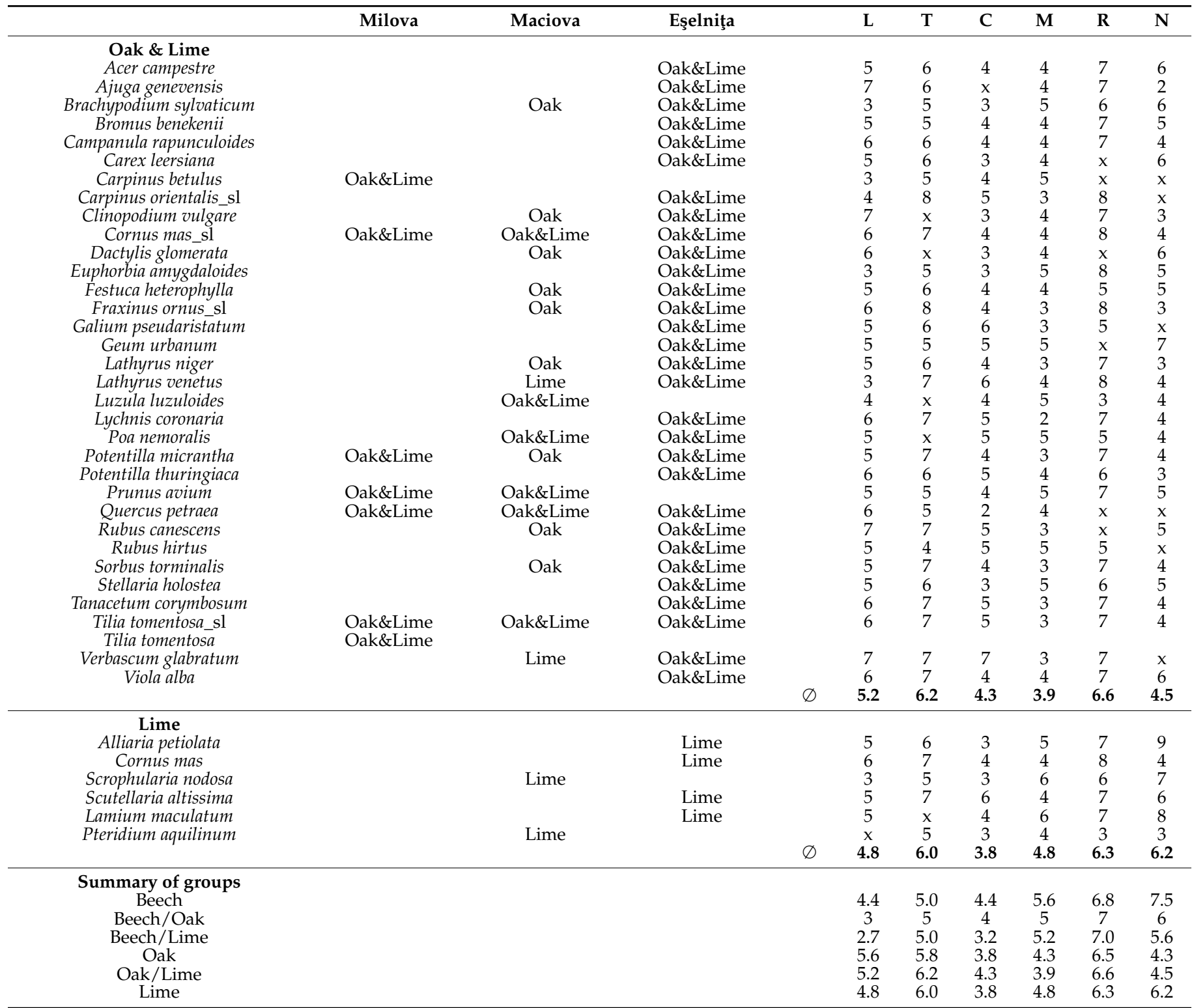

\section{References}

1. Machar, I.; Vlckova, V.; Salek, L.; Pechanec, V.; Nowak, A.; Nowak, S.; Plasek, V.; Svajda, J.; Oprsal, Z.; Topacoglu, O. Environmental Modelling of Forest Vegetation Zones as A Support Tool for Sustainable Management of Central European Spruce Forests. J. Landsc. Ecol. 2018, 11, 45-63. [CrossRef]

2. Buras, A.; Menzel, A. Projecting Tree Species Composition Changes of European Forests for 2061-2090 Under RCP 4.5 and RCP 8.5 Scenarios. Front. Plant Sci. 2019, 9, 1986. [CrossRef]

3. Schuldt, B.; Buras, A.; Arend, M.; Vitasse, Y.; Beierkuhnlein, C.; Damm, A.; Gharun, M.; Grams, T.E.; Hauck, M.; Hajek, P.; et al. A first assessment of the impact of the extreme 2018 summer drought on Central European forests. Basic Appl. Ecol. 2020, 45, 86-103. [CrossRef]

4. Gessler, A.; Keitel, C.; Kreuzwieser, J.; Matyssek, R.; Seiler, W.; Rennenberg, H. Potential risks for European beech (Fagus sylvatica L.) in a changing climate. Trees 2006, 21, 1-11. [CrossRef]

5. Hohnwald, S.; Indreica, A.; Walentowski, H.; Leuschner, C. Microclimatic Tipping Points at the Beech-Oak Ecotone in the Western Romanian Carpathians. Forests 2020, 11, 919. [CrossRef]

6. Leuschner, C. Drought response of European beech (Fagus sylvatica L.)-A review. Perspect. Plant Ecol. Evol. Syst. 2020, 47, 125576. [CrossRef]

7. Hof, A.; Dymond, C.C.; Mladenoff, D.J. Climate change mitigation through adaptation: The effectiveness of forest diversification by novel tree planting regimes. Ecosphere 2017, 8, e01981. [CrossRef] 
8. Thom, D.; Keeton, W.S. Disturbance-based silviculture for habitat diversification: Effects on forest structure, dynamics, and carbon storage. For. Ecol. Manag. 2020, 469, 118132. [CrossRef]

9. Pedro, M.S.; Rammer, W.; Seidl, R. Tree species diversity mitigates disturbance impacts on the forest carbon cycle. Oecologia 2015, 177, 619-630. [CrossRef]

10. Ammer, C. Diversity and forest productivity in a changing climate. New Phytol. 2018, 221, 50-66. [CrossRef]

11. Williams, M.I.; Dumroese, R.K. Preparing for Climate Change: Forestry and Assisted Migration. J. For. 2013, 111, 287-297. [CrossRef]

12. Koralewski, T.E.; Wang, H.-H.; Grant, W.E.; Byram, T.D. Plants on the move: Assisted migration of forest trees in the face of climate change. For. Ecol. Manag. 2015, 344, 30-37. [CrossRef]

13. Schmiedinger, A.; Bachmann, M.; Kölling, C.; Schirmer, R. Verfahren zur Auswahl von Baumarten für Anbauversuche vor dem Hintergrund des Klimawandels. Forstarchiv 2009, 80, 15-22.

14. Mette, T.; Brandl, S.; Kölling, C. Climate Analogues for Temperate European Forests to Raise Silvicultural Evidence Using Twin Regions. Sustainability 2021, 13, 6522. [CrossRef]

15. Frischbier, N.; Nikolova, P.S.; Brang, P.; Klumpp, R.; Aas, G.; Binder, F. Climate change adaptation with non-native tree species in Central European forests: Early tree survival in a multi-site field trial. Eur. J. For. Res. 2019, 138, 1015-1032. [CrossRef]

16. Binder, F. Silberlinde-Baumart mit Chancen im Klimawandel? AFZ-Der Wald 2015, 70, 23-27.

17. Pigott, C.D. Lime-Trees and Basswoods: A Biological Monograph of the Genus Tilia; Cambridge University Press: Cambridge, UK; New York, NY, USA, 2012; pp. 1-395.

18. Radoglou, K.; Dobrowolska, D.; Spyroglou, G.; Nicolescu, V.N. A review on the ecology and silviculture of limes (Tilia cordata Mill., Tilia platyphyllos Scop. and Tilia tomentosa Moench.) in Europe. Die Bodenkult. 2009, 60, 7-17.

19. Sjöman, H.; Oprea, A. Potential of Tilia tomentosa Moench, for use in urban environments in north-west Europe, based on habitat studies in north-east Romania and the Republic of Moldova. Ekológia (Bratislava) 2010, 29, 360-372. [CrossRef]

20. Purcelean, S.; Pascovschi, S.; Leandru, V.; Drăgut, N.; Stoiculescu, C. Cercetări tipologice în teișuri și arborete amestecate cu participarea teiului. An. ICAS 1970, 27, 135-162.

21. Zagwijn, W.H. An analysis of Eemian climate in Western and Central Europe. Quat. Sci. Rev. 1996, 15, 451-469. [CrossRef]

22. Kupryjanowicz, M.; Granoszewski, W.; Fiłoc, M. New finds of Eemian Tilia tomentosa Moench macroremais in NE Poland, and the reconstructed European range of this species during the last interglacial. Quat. Int. 2018, 467, 107-116. [CrossRef]

23. Horvat, I.; Glavac, H.; Ellenberg, H. Vegetation Südosteuropas; G. Fischer: Jena, Germany, 1974; pp. 1-767.

24. Marinšek, A.; Šilc, U.; Carni, A. Geographical and ecological differentiation of Fagus forest vegetation in SE Europe. Appl. Veg. Sci. 2012, 16, 131-147. [CrossRef]

25. Coldea, G.; Indreica, A.; Oprea, A. Les Associations Végétales de Roumanie. Tome 3-Les Associations Forestiéres et Arbustives; Presa Universitară Clujeană: Cluj-Napoca, Romania, 2015; pp. 1-281.

26. Indreica, A.; Teodosiu, M.; Petrițan, A.M.; Öder, V.; Kasper, J.; Bergmeier, E.; Leuschner, C.; Gailing, O.; Hohnwald, S.; Wildhagen, H.; et al. Nemoral deciduous forests under climatic extremes-Phytosociological studies along climatic gradients in SW Romania. In Proceedings of the Biennial International Symposium "Forest and Sustainable Development", 8th ed.; Transilvania University Press: Brasov, Romania, 2019; pp. 139-148.

27. European Commission. Interpretation manual of European Union Habitats. EUR 2013, 28, 1-144.

28. Doniță, N.; Purcelean, S. Pădurile de șleau din R.S.România și Gospodărirea lor; Ceres Publishing House: Bucharest, Romania, 1975; pp. 1-185.

29. Dinić, A.L.; Mišić, V.P.; Savić, D.L. Silver Linden (Tilia tomentosa MOENCH) in the community of sessile oak and hornbean (Rusco-Quercetum-Carpinetum, B.Jov. 1979 tilietosum tomentosae subass. nova) on the Fruška Gora Mountain. Matica Srp. Proc. Nat. Sci. 1991, 97, 63-78.

30. Gafta, D.; Mountford, J.O. (Eds.) Manual de Interpretare a Habitatelor Natura 2000 din România; Risoprint: Cluj-Napoca, Romania, 2008; pp. 1-105.

31. Jacquemart, A.-L.; Moquet, L.; Ouvrard, P.; Quetin-Leclercq, J.; Hérent, M.-F.; Quinet, M. Tilia trees: Toxic or valuable resources for pollinators? Apidologie 2018, 49, 538-550. [CrossRef]

32. Hagemeier, M. Funktionale Kronenarchitektur mitteleuropäischer Baumarten am Beispiel von Hängebirke, Waldkiefer, Traubeneiche, Hainbuche, Winterlinde und Rotbuche. Diss. Bot. 2001, 361, 1-154.

33. Šebesta, J.; Maděra, P.; Ǩepka, R.; Matula, R. Comparison of vascular plant diversity and species composition of coppice and high beech forest in the Banat region, Romania. Folia Geobot. Phytotaxon. 2017, 52, 33-43. [CrossRef]

34. Anca, T. Teiul Și Rolul lui în Producția Forestieră din România [Lime and Its Role in Romanian Forestry]. Ph.D. Thesis, University of Brașov, Brasov, Romania, 1969.

35. Mette, T.; Dolos, K.; Meinardus, C.; Bräuning, A.; Reineking, B.; Blaschke, M.; Pretzsch, H.; Beierkuhnlein, C.; Gohlke, A.; Wellstein, C. Climatic turning point for beech and oak under climate change in Central Europe. Ecosphere 2013, 4, 1-19. [CrossRef]

36. Öder, V.; Petritan, A.M.; Schellenberg, J.; Bergmeier, E.; Walentowski, H. Patterns and drivers of deadwood quantity and variation in mid-latitude deciduous forests. For. Ecol. Manag. 2021, 487, 118977. [CrossRef]

37. Kottek, M.; Grieser, J.; Beck, C.; Rudolf, B.; Rubel, F. World Map of the Köppen-Geiger climate classification updated. Meteorol. Z. 2006, 15, 259-263. [CrossRef]

38. Nicolescu, V.N. The Practice of Silviculture; Aldus: Brasov, Romania, 2018; pp. 1-254. 
39. Doniță, N.; Ivan, D.; Coldea, G.; Sanda, V.; Popescu, A.; Chifu, T.; Paucă-Comănescu, M.; Mititelu, D.; Boscaiu, N. Vegetația României; Tehnică Agricolă: Bucuresti, Romania, 1992.

40. Karger, D.N.; Conrad, O.; Boehner, J.; Kawohl, T.; Kreft, H.; Soria-Auza, R.W.; Zimmermann, N.; Linder, H.P.; Kessler, M. Climatologies at high resolution for the earth's land surface areas. Sci. Data 2017, 4, 170122. [CrossRef]

41. Van der Maarel, E.; Franklin, J. (Eds.) Vegetation Ecology, 2nd ed.; Wiley-Blackwell: Oxford, UK, 2013.

42. Sârbu, I.; Ștefan, N.; Oprea, A. Plante Vasculare din România. Determinator Ilustrat de Teren; Victor Publishing House: Bucharest, Romania, 2013.

43. Hoppmann, D. Die direkte Sonneneinstrahlung. In Die Standortkartierung der hessischen Weinbaugebiete; Löhnertz, O., Hoppmann, D., Emde, K., Friedrich, K., Schmanke, M., Zimmer, T., Eds.; Hessisches Landesamt für Naturschutz, Umwelt und Geologie: Wiesbaden, Germany, 2004; Volume 114, pp. 27-38.

44. Dormann, C.F.; Bagnara, M.; Boch, S.; Hinderling, J.; Janeiro-Otero, A.; Schäfer, D.; Schall, P.; Hartig, F. Plant species richness increases with light availability, but not variability, in temperate forests understorey. BMC Ecol. 2020, 20, 43. [CrossRef]

45. Sercu, B.K.; Baeten, L.; Van Coillie, F.; Martel, A.; Lens, L.; Verheyen, K.; Bonte, D. How tree species identity and diversity affect light transmittance to the understory in mature temperate forests. Ecol. Evol. 2017, 7, 10861-10870. [CrossRef] [PubMed]

46. Gelman, A.; Su, Y.-S. Arm: Data Analysis Using Regression and Multilevel/Hierarchical Models. R package Version 1.11-2. 2020. Available online: https: / /CRAN.R-project.org/package=arm (accessed on 16 July 2021).

47. Grueber, C.E.; Nakagawa, S.; Laws, R.J.; Jamieson, I.G. Multimodel inference in ecology and evolution: Challenges and solutions. J. Evol. Biol. 2011, 24, 699-711. [CrossRef] [PubMed]

48. Kamil, B. MuMIn: Multi-Model Inference. R Package Version 1.43.17. Available online: https://CRAN.R-project.org/package= MuMIn (accessed on 16 July 2021).

49. Wood, S.N. Fast stable restricted maximum likelihood and marginal likelihood estimation of semiparametric generalized linear models. J. R. Stat. Soc. Ser. B Stat. Methodol. 2010, 73, 3-36. [CrossRef]

50. Bates, D.; Mächler, M.; Bolker, B.; Walker, S. lme4: Linear mixed-effects models using Eigen and SR package version 1.1. J. Stat. Softw. 2015, 67, 1-48. [CrossRef]

51. Muggeo, V.M.R. Estimating regression models with unknown break-points. Stat. Med. 2003, 22, 3055-3071. [CrossRef]

52. Ellenberg, H. Vegetation Mitteleuropas mit den Alpen, 5th ed.; Ulmer: Stuttgart, Germany, 1996.

53. Oksanen, J.; Blanchet, F.G.; Kindt, R.; Legendre, P.; Minchin, P.R.; O’hara, R.; Simpson, G.L.; Solymos, P.; Stevens, M.; Wagner, H. Vegan: Community Ecology Package. R Package Version 2.4-2. Available online: http:/ /CRAN.R-project.org/package=vegan (accessed on 16 July 2021).

54. De Cáceres, M.; Legendre, P. Associations between species and groups of sites: Indices and statistical inference. Ecology 2009, 90, 3566-3574. [CrossRef] [PubMed]

55. Vilches, B.; De Cáceres, M.; Sánchez-Mata, D.; Gavilán, R.G. Indicator species of broad-leaved oak forests in the eastern Iberian Peninsula. Ecol. Indic. 2013, 26, 44-48. [CrossRef]

56. Chao, A.; Gotelli, N.J.; Hsieh, T.C.; Sander, E.L.; Ma, K.H.; Colwell, R.K.; Ellison, A. Rarefaction and extrapolation with Hill numbers: A framework for sampling and estimation in species diversity studies. Ecol. Monogr. 2014, 84, 45-67. [CrossRef]

57. Heinrichs, S.; Ammer, C.; Mund, M.; Boch, S.; Budde, S.; Fischer, M.; Müller, J.; Schöning, I.; Schulze, E.-D.; Schmidt, W.; et al. Landscape-Scale Mixtures of Tree Species are More Effective than Stand-Scale Mixtures for Biodiversity of Vascular Plants, Bryophytes and Lichens. Forests 2019, 10, 73. [CrossRef]

58. Katona, K.; Kiss, M.; Bleier, N.; Székely, J.; Nyeste, M.; Kovács, V.; Terhes, A.; Fodor, Á.; Olajos, T.; Rasztovits, E.; et al. Ungulate browsing shapes climate change impacts on forest biodiversity in Hungary. Biodivers. Conserv. 2013, 22, 1167-1180. [CrossRef]

59. Schädler, M.; Brandl, R. Do invertebrate decomposers affect the disappearance rate of litter mixtures? Soil Biol. Biochem. 2005, 37, 329-337. [CrossRef]

60. Mölder, A.; Bernhardt-Römermann, M.; Leuschner, C.; Schmidt, W. Zur Bedeutung der Winterlinde (Tilia cordata Mill.) in mittelund nordwestdeutschen Eichen-Hainbuchen-Wäldern. Tuexenia 2009, 29, 9-23.

61. De Jaegere, T.; Hein, S.; Claessens, H. A Review of the Characteristics of Small-Leaved Lime (Tilia cordata Mill.) and Their Implications for Silviculture in a Changing Climate. Forests 2016, 7, 56. [CrossRef]

62. Mölder, A.; Bernhardt-Römermann, M.; Schmidt, W. Herb-layer diversity in deciduous forests: Raised by tree richness or beaten by beech? For. Ecol. Manag. 2008, 256, 272-281. [CrossRef]

63. Dimitrova, V.G. Distribution and Assessment of the Nature Conservational Status of the Nature Habitat 91Z0 "Moesian Silver Lime Forests" in SCI "Svishtovska Gora" (BG0000576), Bulgaria. Ecol. Balk. 2015, 7, 13-19.

64. Vockenhuber, E.A.; Scherber, C.; Langenbruch, C.; Meißner, M.; Seidel, D.; Tscharntke, T. Tree diversity and environmental context predict herb species richness and cover in Germany's largest connected deciduous forest. Perspect. Plant Ecol. Evol. Syst. 2011, 13, 111-119. [CrossRef]

65. Le Due, M.; Havill, D. Competition between Quercus petraea and Carpinus betulus in an ancient wood in England: Seedling survivorship. J. Veg. Sci. 1998, 9, 873-880. [CrossRef]

66. Chudomelová, M.; Hédl, R.; Zouhar, V.; Szabó, P. Open oakwoods facing modern threats: Will they survive the next fifty years? Biol. Conserv. 2017, 210, 163-173. [CrossRef]

67. Mölder, A.; Streit, M.; Schmidt, W. When beech strikes back: How strict nature conservation reduces herb-layer diversity and productivity in Central European deciduous forests. For. Ecol. Manag. 2014, 319, 51-61. [CrossRef] 
68. Brändle, M.; Brandl, R. Species richness of insects and mites on trees: Expanding Southwood. J. Anim. Ecol. 2001, 70, 491-504. [CrossRef]

69. Vogel, S.; Bussler, H.; Finnberg, S.; Müller, J.; Stengel, E.; Thorn, S. Diversity and conservation of saproxylic beetles in 42 European tree species: An experimental approach using early successional stages of branches. Insect Conserv. Divers. 2021, 14, 132-143. [CrossRef]

70. Machar, I.; Vozenilek, V.; Simon, J.; Pechanec, V.; Brus, J.; Fulnecek, P.; Vitek, T. Joining of the historical research and future prediction as a support tool for the assessment of management strategy for European beech-dominated forests in protected areas. Nat. Conserv. 2017, 22, 51-78. [CrossRef]

71. Montwé, D.; Isaac-Renton, M.; Hamann, A.; Spiecker, H. Cold adaptation recorded in tree rings highlights risks associated with climate change and assisted migration. Nat. Commun. 2018, 9, 1574. [CrossRef] [PubMed]

72. Walentowski, H.; Falk, W.; Mette, T.; Kunz, J.; Bräuning, A.; Meinardus, C.; Zang, C.; Sutcliffe, L.M.; Leuschner, C. Assessing future suitability of tree species under climate change by multiple methods: A case study in southern Germany. Ann. For. Res. 2014, 60, 101-126. [CrossRef] 